\title{
Married to the firm? A large scale investigation of the social context of ownership
}

\author{
Sharon Belenzon ${ }^{1}$, Andrea Patacconi ${ }^{2}$ and Rebecca Zarutskie ${ }^{3}$
}

\begin{abstract}
Research summary: Using a large sample of private firms across Europe, we examine how the social context of owners affects firm strategy and performance. Drawing on embeddedness theory and the institutional logics perspective, we argue that embeddedness in a family, in particular the nuclear family, can strengthen identification and commitment to the firm, but can also induce owners to behave more conservatively. Consistent with this argument, we find that family-owned firms have higher profit margins, returns on assets, and survival rates compared to single-owner or unrelatedowners' firms, but also invest and grow more slowly, hold greater reserves of cash, and rely less on external debt. These differences are most pronounced when the two largest shareholders are married. Our results highlight the key role of marital ties in explaining differences in behavior and performance among firms.
\end{abstract}

Managerial summary: Despite the prevalence of the married couple ownership structure in firms, little research has been dedicated to understanding how these firms are managed and perform. We examine the behavior and performance of firms owned by married couples in a large panel of closely held Western European firms. We find that married-owners family firms are managed more conservatively relative to firms with unrelated owners and even to other family-owned firms. In particular, married-owners family firms invest and grow more slowly and rely less on external finance. However, they also exhibit greater performance stability and higher profitability. Our findings suggest that social relationships among owners have a large impact on firm strategy and performance, and highlight some potential trade-offs to performance when married couples control firms.

Keywords: Social context, institutional logics, family ownership, marital ties, conservatism

JEL Classification: G32, G18, O16

This article has been accepted for publication and undergone full peer review but has not been through the copyediting, typesetting, pagination and proofreading process, which may lead to differences between this version and the Version of Record. Please cite this article as doi: $10.1002 / \mathrm{smj} .2441$

\footnotetext{
${ }^{1}$ Duke University, Fuqua School of Business

${ }^{2}$ University of East Anglia, Norwich Business School

${ }^{3}$ Federal Reserve Bank
}

This article is protected by copyright. All rights reserved. 


\section{Introduction}

Family firms are prevalent across the world and comprise a significant share of assets and economic activity. It is fitting, therefore, that researchers have devoted significant effort to understanding how family involvement in a business affects corporate strategy. Most scholars concur that a fundamental difference between family and non-family firms is that factors such as emotional attachment to the firm and affective ties among owners play a more important role in family firms than in non-family firms (Gersick et al., 1997; Gomez-Mejia et al., 2007). However, a systematic examination of these factors is still largely missing (Berrone et al., 2012; Chrisman et al., 2005). In this paper, we examine the social context of ownership. We distinguish among different types of social ties among owners and show that these distinctions have important consequences for firm strategy and performance.

Previous research on the effects of family ownership has yielded mixed or conflicting results. On the one hand, the literature suggests that, especially among founder-managed firms and in developed countries, family ownership improves financial performance (Villalonga and Amit, 2006; Miller et al., 2008; Minichilli et al., 2010). On the other hand, family ownership has been associated with a number of problems, including low investment, conservative cash policies, and slow growth (Mishra and McConaughy, 1999; Gallo et al., 2004; Block, 2012; Miller et al., 2013; Patel and Chrisman, 2014). Drawing on embeddedness theory (Granovetter, 1985; Uzzi, 1997; Le Breton-Miller and Miller, 2009, 2011) and the institutional logics perspective (Friedland and Alford, 1991; Thornton and Ocasio, 2008; Miller et al., 2011), we argue that these findings cannot be properly understood without examining the social context in which owners operate. Institutional logics provide social actors with "assumptions and values, usually implicit, about how to interpret organizational reality, what constitutes appropriate behavior, and how to succeed" (Thornton, 2004: 70). The social context of ownership, as captured by the nature and intensity of affective ties among shareholders, can influence how owners manage their firms (Gomez-Mejia et al., 2001; Greenwood et al., 2007;

This article is protected by copyright. All rights reserved. 
Miller et al., 2011). Lone owners, or owners with no affective ties to other shareholders, may be more willing to take on risk and adopt strategies of growth. Family owners, by contrast, may perceive themselves as 'family nurturers' and may use the firm to generate stable, secure income for family members (Miller et al., 2011). This conservative logic is likely to be most pronounced among married owners who may perceive the firm as a legacy or bequest to their children. These altruistic concerns may translate into a concern for the long-term performance and survival of the firm, which may induce married owners to both work hard (thus raising profits) and behave conservatively.

We study the social context of ownership using detailed data on a large panel of private firms across Europe. We distinguish among lone or single owners, family owners, and unrelated owners. We define family-owned firms as those having at least two shareholders with the same last name holding a majority of the company shares. Thus, our focus is on family ties between owners, rather than family ties between employees and owners or between current and future owners. Familyowned firms represent $25 \%$ of firms in our sample of 228,253 firms, and almost $40 \%$ of the 152,245 firms with at least two shareholders. Among family-owned firms, we distinguish between firms that are predominantly owned by a married couple versus those that are predominantly owned by other types of family members, such as parents and children or siblings.

Our analysis indicates that family owners are associated with more conservative management strategies and slower growth. Family-owned firms rely more on internal cash reserves and less on outside debt when financing their assets. Also, sales growth and investment rates at family-owned firms are on average lower than at non-family-owned firms. Associated with these more conservative strategies are stronger measures of financial performance. Family-owned firms on average have higher returns on assets, profit margins, and survival rates than non-family-owned firms. The ability or willingness of family owners to keep wages down partly explains their superior financial performance.

This article is protected by copyright. All rights reserved. 
The results are strongest for firms whose two largest shareholders are married. Married owners are especially likely to adopt conservative strategies relative to other types of owners. The results hold both cross-sectionally and when focusing only on firms that experience ownership changes and are strengthened when instrumenting for married family ownership. We control for several factors that could bias our results, such as differences between genders and ownership concentration at the family level, and find that our results are robust. One important caveat is that the vast majority of firms in our sample are very small---the median firm has just 8 employees. For the owners of these small firms, providing a secure source of income to family members is likely to be a major concern. More research is needed to establish to what extent our findings generalize to much larger familyowned firms.

Our paper contributes to a literature examining how owners' and managers' social context affects firm strategy and performance (Uzzi, 1996, 1997; Carpenter, 2002; Miller et al., 2010; Minichilli et al., 2010). Our results do not support the agency-theoretic view that family-owned firms perform better and are more likely to survive because there are fewer conflicts of interest among owners or better monitoring between owners and managers (Jensen and Meckling, 1976). Indeed, familyowned firms exhibit higher returns, profits and survival relative to single-owner firms, in which conflicts of interest among owners are absent. The results also do not support the simplistic view that being part of the same family is sufficient to eliminate agency conflicts or enhance motivation. We find significant differences between types of family owners, suggesting that the intensity of family ties strongly influences owners' values and behaviors. In particular, marriage appears to be associated with a change in logics that puts greater weight on preserving wealth for future generations. This is consistent with the idea that people's propensity to take risks changes over time depending on how they frame their personal circumstances (Wiserman and Gomez- Mejia, 1998). The evidence also supports the institutional logics' view that the symbolic and material aspects of organizational life are closely intertwined (Friedland and Alford, 1991; Thornton and Ocasio, 2008),

This article is protected by copyright. All rights reserved. 
and that marriage is a ritual that reinforces a specific set of beliefs and obligations (Thornton et al., 2012).

From a more general standpoint, our analysis underscores the importance of distinguishing between different types of affective ties when theorizing about family firms, and points to the key role of marital ties in explaining inter-firm differences in strategy and performance.

\section{Theoretical background}

\section{The notion of "family" in family firms}

There is no universally accepted definition of a family firm. Most definitions in the literature are operational, focusing on some combination of dimensions of family involvement in a business, such as ownership, management, and transgenerational succession (Chua et al., 1999; Miller et al., 2007). Some authors for instance define family firms as those owned and controlled by a single individual or a family, while others define family firms as those that are both owned and managed by family members.

An even more basic problem, rarely addressed in the literature, is what is meant by "family" in the family firm context. One key distinction is the one between lone owners or founders and broader family involvement (Miller et al., 2007; Miller et al., 2011). Microsoft, for instance, is classified as a "family" firm by Anderson and Reeb (2003) but, as Dyer (2006) notes, while the impact of Bill Gates the founder cannot be underestimated, the effect of the Gates family on the firm is much more debatable. On the other hand, it is difficult to downplay the role of the family and transgenerational succession in firms such as Wal-Mart, Koch Industries and In-N-Out Burger.

When family involvement is deemed as important, the issue arises of how to delimit family boundaries. Anthropologists have long noted that the concept of family is a culturally ambiguous one, for the type and intensity of family ties vary considerably between groups and cultures (Levi-

This article is protected by copyright. All rights reserved. 
Strauss, 1969; Eller, 2009). In everyday Western discourse, the term family typically refers to "a group of people related to one another by blood or marriage" (Oxford Dictionary). This definition highlights the two fundamental mechanisms that give rise to families: the "horizontal" principle of marriage, which "links different individuals (and groups) together and establishes new groups," and the "vertical" principle of descent, which links "individuals and groups through time and "down" between the generations" (Eller, 2009: 182).

To be sure, focusing exclusively on the principles of marriage and descent can be restrictive. The emotions that are thought to differentiate family firms from non-family firms---a sense of togetherness, shared vision and destiny, mutual trust, etc.---can also be found in groups larger than the nuclear or extended family (Stewart, 2003; Karra et al., 2006). To emphasize this, Peredo (2003) introduces the term "kin-based business" to extend the traditional family firm construct beyond the biological family and to include spiritual relations marked by social, cultural and religious rituals of incorporation. Karra et al. (2006) similarly stress the importance of distant kin and ethnic ties (the "quasi-family") in a business context.

In this paper, we use the term "family" in the traditional but more restrictive sense of a group of people related to one another by blood or marriage. In the empirical part, we refer to firms whose owners are family members as family-owned firms, and include in the set of family-owned firms only those that have two or more family-related shareholders. Firms owned by a single individual are categorized as single-owner firms. Thus, we distinguish between (multi-person) family owners and lone, or single, owners. Among family owners, special attention is paid to owners that are married to each other. By contrast, when reviewing the existing literature, as in the next subsection, we will typically use the all-embracing term "family firm," due to the aforementioned heterogeneity in definitions used.

\section{The "family effect" on firm performance}

This article is protected by copyright. All rights reserved. 
Since its inception, family firm research has been concerned with identifying differences in performance and behavior between family and non-family firms. In so doing, it has highlighted several economic and non-economic factors that can potentially be responsible for these differences.

Among the economic factors, two occupy center stage: lack of wealth and human capital diversification and agency problems. Family owners typically have a large portion of their wealth tied up in their firm; moreover, to the extent that they also manage their firms, their human capital is also tied to the business. This lack of diversification can induce family owners to avoid risk and behave conservatively, compared to the shareholders of widely held corporations (Eisenhardt, 1989; Beatty and Zajac, 1994).

Family and non-family firms also differ in the extent to which they are affected by different types of agency problems. The fundamental agency problem in widely held corporations stems from the separation of ownership and control (Jensen and Meckling, 1976). Managers who have only a limited stake in a company may use their power to further their own interests at the expense of company shareholders. The separation of ownership and control is typically a much less severe problem in family firms, where ownership is often highly concentrated and management and ownership tend to coincide. On the other hand, concentrated family ownership can give rise to a 'principal-principal' problem, whereby family shareholders extract private benefits of control from their companies, at the expense of minority shareholders (Bertrand and Schoar, 2006; Feldman et al., 2014).

Family and non-family firms also differ in the extent to which they are affected by non-economic factors. As a general rule, non-economic factors are believed to play a much more important role in family firms than in non-family firms (Gersick et al., 1997; Gomez-Mejia et al., 2007). Non-economic factors can complement business values, thus creating competitive advantage, or can conflict with business values, thus creating competitive disadvantage. Identification with the firm, for instance, may induce family members to work hard and not give up in the face of adversity. On the other

This article is protected by copyright. All rights reserved. 
hand, parents may have biased views about the ability of their children or may find it difficult not to grant them important positions in their firms. Thus, nepotistic practices may be commonplace in family firms.

Because so many factors can affect family and non-family firms, establishing whether family ownership is beneficial or detrimental to firm performance is fundamentally an empirical question. Moreover, empirical findings are likely to be context-specific---dependent on the type of firms, owner characteristics, performance measures and institutional settings considered. Among the numerous studies that have examined performance differences between family and non-family firms, many have found that, especially when the founder still manages the firm and in developed countries, family ownership is associated with superior financial performance (Villalonga and Amit, 2006; Miller et al., 2008). However, when succession occurs, problems tend to arise. For instance, Villalonga and Amit's (2006) and Perez-Gonzalez's (2006) results indicate that, in family firms, capable founders are often replaced by less capable family heirs. Likewise, Miller et al. (2013) find that family CEOs underperform as firms get larger and shareholders more dispersed, and Minichilli et al. (2010) find that factions in family management teams can worsen firm performance.

\section{Unbundling the "family effect": institutional logics and the social context of owners}

The literature discussed above suggests that the identity of firm owners is a key determinant of firm performance. In this paper, we delve deeper into the identities and social roles of firm owners. Drawing on embeddedness theory and the institutional logics perspective, we argue that close affective ties between owners influence how they manage their firms.

Institutional logics, such as those of the market or the family, provide owners with assumptions, cognitive frames and values that allow them to interpret organizational reality (Friedland and Alford, 1991; Thornton and Ocasio, 2008). They are "formal and informal rules of action, interaction, and

This article is protected by copyright. All rights reserved. 
interpretation that guide and constrain decision makers" (Thornton, 2004: 2); they also "guide the allocation of attention by shaping what problems and issues get attended to and what solutions are likely to be considered in decision making" (Thornton et al., 2012: 90; Ocasio, 1997). Logics have been found to influence organizational practices, such as in the context of leadership succession and human resource management (Thornton and Ocasio, 1999; Westphal and Zajac, 1994; Chung and Luo, 2013), firm downsizing (Greenwood et al., 2010), and social responsibility (Lounsbury, 2007). Embeddedness theory helps to explain how logics emerge. Embeddedness theory holds that economic action is influenced by the social context in which agents operate: "[p]eople live within networks of relationships where information, ideas, passions, and values are shared" (Le BretonMiller and Miller, 2009: 1176; Granovetter, 1985; Uzzi, 1997). Embeddedness in a social structure can promote economic performance by facilitating coordination, cooperation and information exchange between agents (Uzzi, 1996; Gulati et al., 2000; Uzzi and Gillespie, 2002), but can also impede it if relationships become hostile (Uzzi, 1996; Walter et al., 2014). A social structure in which virtually all owners are embedded in is the family. Building on Miller et al. (2011), we distinguish between single (or lone) owners and family owners. Single owners can have families, but their families do not hold significant stakes in their firms. By contrast, family owners are defined as two or more family-related individuals who hold significant stakes in the same firm.

Because family owners are likely to live and work in proximity to each other and to be exposed to each other's needs, they may develop a more familiar orientation than single owners or familyunrelated owners (Le Breton-Miller and Miller, 2009, 2011; Miller et al., 2011). They may come to perceive them- selves as 'family nurtures' and may develop a conservative logic that emphasizes the preservation of wealth for future generations.

Greater embeddedness within the family can engender conservatism for a number of reasons. First, to preserve family harmony, compromise and unanimity among family owners may be sought. But compromise and unanimity can make change more difficult to happen, hampering investment and

This article is protected by copyright. All rights reserved. 
growth. Strong ties among the members of a group may also promote conformity and resistance to change (Granovetter, 1973; Bantel and Jackson, 1989). Sentiments such as, "things are done this way because Dad did them this way" are commonplace in family-owned firms (Leach, 2007: 11). Family owners may also frequently remind each other that their primary duty is to provide income and security to the whole family. They may be particularly reluctant to invest and/or take on debt, as these strategies may compromise family control and welfare. By contrast, single or unrelated owners may develop weaker "bridging" ties with a multiplicity of stakeholders. This may favor a less parochial agenda, and engender a more entrepreneurial logic. Thus, single or unrelated owners may be more likely than family owners to adopt strategies of growth (Miller et al., 2011).

Hypothesis 1. Family-owned firms will adopt more conservative strategies than single-owner and unrelated-owners firms.

The identity of the owners of a firm can also affect firm performance (Rumelt, 1991; Villalonga and Amit, 2006; Xia and Walker, 2015). However, how the values and priorities of family owners may affect firm performance is, a priori, unclear. On the one hand, conservative strategies that fail to invest in the future can be detrimental to performance (Miller et al., 2007; Miller et al., 2011). On the other hand, some entrepreneurs are overly optimistic, and a more cautious strategic approach can help offset this. Moreover, in the short term at least, cutting investment boosts profits by reducing expenditures.

More conservative policies can also increase profitability by allowing firms to reduce their wage costs. If family-owned firms are managed more conservatively and have lower probability of failure (as we document in this paper), then they may be able to pay lower wages, or defer wages, since employees have less risk of losing their job. Consistent with this view, Sraer and Thesmar (2007) find

This article is protected by copyright. All rights reserved. 
that, among publicly traded French firms, family ownership, especially when the firm is heirmanaged, is associated with lower wages even after controlling for the firm's skill structure, and employment is smoothed out over the business cycle. Sraer and Thesmar suggest that many familyowned firms, in exchange for lower wages, provide their workers with long-term implicit insurance contracts.

Finally, a familiar orientation can boost performance for reasons unrelated to conservatism. It has long been noted in the family firm literature that a familiar orientation can be a source of competitive advantage by increasing commitment to the long-term success of the firm. For instance, the desire to preserve family control and firm value for future generations may motivate family owners to adopt more efficient business practices (Colli, 2002).

Hypothesis 2. Family-owned firms will exhibit superior financial performance relative to singleowner and unrelated-owners firms.

\section{The effect of marital ties}

Miller et al. (2011) distinguish between lone founders and family owners, but do not examine the different types of bonds that exist between family owners. Yet, some bonds are obviously stronger than others, and owners' values and priorities may be shaped by the intensity of such bonds.

Embeddedness theory also emphasizes the importance of heterogeneity in social ties (Granovetter, $1973,1985)$ and suggests that different logics are embedded in different systems of social relations (Uzzi, 1996, 1997). For instance, Uzzi $(1996,1997)$ finds in his study of New York's apparel industry that one-shot, anonymous transactions ("market ties") are characterized by a market logic where costs or money are everything, while long-term relationships ("embedded ties") exhibit a logic of exchange where trust, fine-grained information transfer and joint problem solving feature

This article is protected by copyright. All rights reserved. 
prominently. Long-term, emotionally close relationships ("strong ties") have also been associated with group think, risk-aversion, and adherence to the status quo (Granovetter, 1973; Bantel and Jackson, 1989).

The bond between husband and wife is undoubtedly one the strongest family ties. Married couples constitute the basis of the nuclear family---a household consisting of a father, a mother, and their children. In terms of strength, marital ties arguably rank second only to the bond between parent and child, and they can be further 'cemented' by the appearance of children. Thus, the literature on embeddedness suggests that firms owned by married couples may display particularly high levels of risk-aversion and adherence to the status quo.

An important reason why married owners may adopt particularly conservative management and cash policies is that married owners may come to perceive the firm as a legacy or bequest to their children. They may be concerned that, by pursuing risky strategies, this bequest may be squandered. Other types of family owners such as sons and daughters may be less risk-averse because for them legacy concerns are less salient. Institutional logics researchers have similarly pointed out that marriage is a ritual that reinforces a specific set of obligations---those "oriented to the reproduction of family members" (Thornton et al., 2012: 44). The conservative logic of married owners can be also reinforced through deliberation. Conversations between husband and wife often revolve around children and their welfare. By contrast, two brothers, even if both married, may discuss familyrelated matters less, and may focus more on growing the business. Thus, the conservative logic of family owners may be especially strong among married owners.

Hypothesis 3. Married-owners' family firms will adopt more conservative strategies than nonmarried- owners' family firms.

This article is protected by copyright. All rights reserved. 
Concerns for the welfare of children may not only induce married owners to behave more conservatively, but may also motivate them to work hard. Research in psychology and evolutionary biology suggests that altruism is strongly asymmetric: Parents care much more about their children's welfare than children care about the welfare of their parents or that of their siblings (see, for instance, Dawkins, 2006). Thus, to the extent that married owners have or will have children, they may exhibit particularly strong altruistic motives. They may work hard to provide for their children, especially young ones. In addition, because married couples typically live together and jointly own many common resources outside the firm, they may be better able to monitor one another, trade information, and enforce implicit contracts relative to other types of owners. Consistent with this, Parker (2008) finds evidence of stronger knowledge spillovers between married owners relative to non-married owners, and Wong (1986) shows that family businesses may utilize human capital resources to greater effect and increase the gains from marriage.

Given such motivations, we expect ownership by married couples to be associated with superior financial performance.

Hypothesis 4. Married-owners family firms will exhibit superior financial performance than nonmarried- owners family firms.

The primary implication that follows from our analysis is that married owners in particular should display a conservative orientation and a commitment to the long-term success of the firm (leading to superior financial performance). We view this familiar orientation or logic as a natural consequence of altruistic concerns for the welfare of future generations. These issues are likely to be prominent especially for small business owners, who are most likely to be concerned with providing income security to other family members. We also expect non-married family owners to exhibit a

This article is protected by copyright. All rights reserved. 
conservative orientation and a commitment to the long-term success of the firm, albeit to a lesser extent than married family owners.

\section{Data}

We obtain our data from Amadeus, a database maintained by Bureau van Dijk (BvD) that contains ownership and financial statement information for firms in several European countries. BvD obtains its data from regulatory filings as well as from its own proprietary sources and includes both private and public firms in its data collection. Amadeus also contains detailed ownership information, including the names of each shareholder, the number of shares held, and detailed information on the board of directors and management of each firm.

We build our sample from firms located in Western European countries. $48 \%$ of the firms are from France, $28 \%$ are from Spain, $20 \%$ are from Great Britain and the remaining firms, $4 \%$, are from Italy. German firms are excluded because they do not report information on profits or assets. We also eliminate observations from countries such as Norway and Denmark for which there are few nonmissing observations for our variables of interest. We retain only those firms for which we have ownership information, and we exclude any firms for which we are unable to identify at least $90 \%$ of reported shareholders and those whose annual sales and profits are not reported. This leaves us with 228,253 firms and 1,258,172 observations for the period 1997-2006.

\section{Classification of firms into ownership categories}

We split our firm sample by ownership type using four basic ownership categories: lone or single owners, married family owners, non-married family owners, and unrelated owners. A fifth ownership category, family owners, aggregates the categories of married family owners and nonmarried family owners.

This article is protected by copyright. All rights reserved. 
We classify a firm as having a single owner if it has only one registered shareholder. We classify a firm as having unrelated owners if the two leading shareholders do not have the same last name and there is no family name that in aggregate holds the majority of equity stakes. We classify a firm as family-owned if at least two shareholders have the same last name and hold a majority of the company shares. A family-owned firm is said to have married owners if the two leading shareholders have the same last name and are of different gender. Gender information is taken from several sources. First, for a subset of shareholders (shareholders that also appear on the firm's manager or director lists), Amadeus provides a gender variable. Second, in many cases, names include a "Mr." or "Mrs." prefix which explicitly identifies the person's gender. Third, for the set of shareholders for whom Amadeus does not identify a gender, we use several public sources to learn about the most common male and female names for different countries. ${ }^{4}$ This classification scheme for marriedowners family firms may include some firms in which the leading shareholders are not married, e.g., those owned by a brother and sister, and may exclude some firms in which the leading shareholders are married but in which the wife does not take the husband's last name. Misclassification will introduce measurement error into our measures, biasing our estimates against finding any differences between ownership categories. We also examine "cleaner" definitions of married family owners for a smaller sample of firms and report on this analysis in Section 5.6. Finally, we classify a firm as having non-married family owners if the two leading shareholders have the same last name and are of the same gender.

$23 \%$ of firms in our sample are classified as family-owned. Of these, $41 \%$ have married owners, and $59 \%$ have non-married family owners. $41 \%$ of our firms fall in the unrelated owner category, while $36 \%$ fall in the single owner category. Family-owned firms are common in all industries, comprising up to $50 \%$ of the firms in such industry segments as automotive repair and agriculture, and as little as $10 \%$ in industry segments such as accounting and advertising.

\footnotetext{
${ }^{4}$ For example, http://names.mongabay.com/male_names.htm.
} 


\section{Descriptive statistics}

In this section we present descriptive statistics for the key variables we analyze in our estimation sample.

Table 1 reports descriptive statistics for the full sample. The average firm in our sample holds $\$ 2.6$ million in total assets, generates $\$ 3.7$ million in annual sales, has 24 employees, is 12 years old, and makes $\$ 157$ thousand in profits (EBITDA). The median firm has 8 employees and the 90th percentile firm has 44 employees. Thus, our dataset predominantly covers very small firms. Return on assets (ROA) and profit margin are computed as earnings before interest, taxes, depreciation, and amortization (EBITDA) over total assets, and EBITDA over sales, respectively. Both variables are winsorized above and below 2 and -2. Average ROA and profit margin are 0.132 and 0.076 (medians of 0.107 and 0.056 ). On average, firms have leverage ratios (the ratio of debt to assets) just under 0.75 and liquidity ratios (the ratio of cash to assets) of 0.286 . Annual sales growth averages is $0.20 .^{5}$

\section{[Insert Table 1 here]}

Table 2 compares the means across all four ownership categories. Family-owned firms are on average larger than non-family-owned firms. For instance, married- and non-married-owners family firms have on average 31 and 34 employees, as compared to 21 and 22 employees for unrelatedowners and single-owner firms. For firms with at least two owners, the average firm has 2.5 owners (a median of 2 and a 90th percentile of 4). The distribution of number of owners is similar across

\footnotetext{
${ }^{5}$ The number of observations represented in the panel by family-owned firms is $24.7 \%$, slightly greater than the $23 \%$ of firms in the sample that are family-owned. This is because family-owned firms have more years of observations in the panel compared to non-family-owned firms. One third of the observations are for firms with female owners.
}

This article is protected by copyright. All rights reserved. 
ownership categories (averages of 2.9, 2.6, and 2.4 for family married-owners, family non-marriedowners and unrelated-owners firms, respectively).

Married-owners family firms have higher ROA and profit margins than non-married-owners family firms $(0.175$ versus 0.128 , and 0.096 versus 0.078$)$. Married-owners family firms also have greater liquidity than non-married-owners family firms ( 0.379 versus 0.290$)$. From the sample averages, it does not seem that married-owners family firms have lower sales growth, investment, and leverage than non-married-owners family firms. However, these sample averages do not control for firm, industry, geographical, and time characteristics. Compared to unrelated-owners and single-owner firms, married- and non-married-owners family firms do seem to have greater liquidity and lower sales growth, investment and leverage. ${ }^{6}$

\section{[Insert Table 2 here]}

\section{Estimation methodology}

In this section we empirically examine our four hypotheses in a regression setting using the following equation:

$$
\begin{aligned}
& y_{i t}=\beta_{1} \text { Unrelated }_{i}+\beta_{2} \text { FamilyNonMarried }_{i}+\beta_{3} \text { FamilyMarried }_{i}+ \\
& +\beta_{4} \text { FemaleOwner }_{i}+X^{\prime}{ }_{i t} \beta_{5}+\varphi_{j}+c_{c}+\tau_{t}+\varepsilon_{i t}
\end{aligned}
$$

$y_{i t}$ is a measure of firm behavior or strategy, such as liquidity, leverage, and investment, as well as performance, such as sales growth, ROA and profit margin. Unrelated, FamilyNonMarried, and FamilyMarried are firm ownership dummies. The base ownership category is single owner.

\footnotetext{
${ }^{6}$ We also compare the pooled averages of family- and non-family-owned firms in our sample and test whether the averages are statistically different. We find that family-owned firms, as a group, have higher returns on assets and profit margins and are larger than non-family-owned firms. We also find that family-owned firms, as a group, invest less, grow slower, and are less leveraged and more liquid. Table A1 in the online appendix presents these estimates.
}

This article is protected by copyright. All rights reserved. 
FemaleOwner is a dummy that indicates whether the firm has a leading female owner, to disentangle the impact of married family ownership from the impact of female ownership. $\mathrm{X}$ is a vector of control variables (such as lagged sales and firm age). $\varphi_{j}, c_{c}$, and $\tau_{t}$ are complete sets of three-digit SIC code, country, and year dummies. $\varepsilon_{i t}$ is an iid error term. We also include in some specifications a dummy for family-owned firms, which receives the value of one for married-owners and non-married-owners family firms, and zero for all other firm types.

In reporting the estimation results, we present $p$-values for testing different hypotheses on parameter equality. In particular, we test whether the family ownership coefficients, $\beta_{2}$ and $\beta_{3}$, are jointly equal to the coefficient estimate on unrelated owners, $\beta_{1}$. Due to the panel structure of our data, standard errors are clustered by firm. ${ }^{7}$

Instrumental Variables. Our estimates are prone to classical unobserved heterogeneity concerns: ownership structures may be chosen endogenously based on firm characteristics. For instance, family-owned firms may perform better than other types of firms because families are more reluctant than other types of shareholders to invest in low-quality projects. To mitigate these concerns, we use an instrumental variable strategy that exploits geographical variation in divorce rates at the regional level (thus, within countries), controlling for region-level factors such as GDP, employment rate, geographical size, population size and competitiveness. Firms in our sample span a wide set of regions within Europe. ${ }^{8}$ These regions vary substantially in terms of the prevalence and stability of the marriage institution. ${ }^{9}$

\footnotetext{
${ }^{7}$ To further mitigate concerns that the panel structure of our data affects the statistical significance of our estimates, Table A2 in the online appendix presents our main results using cross-sectional data where financial information is based on the most recent financial statement for each firm in our sample.

${ }^{8}$ For every country we have information on each city address, and for the majority of firms the region within the country. We standardize region names and merge to the two concordance regional OECD tables NUTSlevel3 and NUTS-level2. These codes allow us to merge regional information to our original firm sample. ${ }^{9}$ Summary statistics for region divorce rate are reported in Table 1 . Summary statistics for region control variables are available from the authors upon request. For instance, the average and median values of GDP are, respectively, 30,774 and 29,468 US dollars. The average and median values of employment rate are 0.63 and 0.65 .
}

This article is protected by copyright. All rights reserved. 
We combine data from several sources. Data on marriage status comes from the 2005-2008 wave of the World Value Survey (WVS). ${ }^{10}$ The survey provides marital status information. Respondents are classified into six categories: married, living together as married, divorced, separated, widowed, and single/never married. We aggregate under married the categories married, living together as married, and widowed. We aggregate under divorced the categories divorced and separated. In addition to marital data, we collect extensive data from OECD and Eurostat on regional development (such as GDP, GDP growth, unemployment rate, education level). ${ }^{11}$ Our final regional data includes information on 107 unique regions (with the four countries in our sample), 119,779 firms (with nonmissing lagged sales values), and 489,562 observations.

Our instrument is the regional divorce rate, which we use as an instrument for whether a firm is a married-owners family firm. We expect that in regions in which divorce is more common, we are less likely to observe married-owners family firms. This is because the number of married couples should be lower, and the expected costs of forming a business with a spouse should be higher when partners perceive divorce as more likely. The necessary identifying assumption is that the underlying drivers of the divorce rate, such as religious norms or the costs of getting a divorce (monetary or psychological), do not impact our firm-level outcome variables other than through the regional divorce rate variable, conditional on regional controls. Note that we do not rely on cross-country variation in marriage rates, but rather regional variation in these measures since we include country fixed effects in all specifications.

Because the sample for which region information is available is considerably smaller than our full sample, to be able to compare the OLS to the IV estimates we also report the OLS results for the subsample of firms with region information.

\footnotetext{
${ }^{10}$ http://www.wvsevsdb.com/wvs/WVSData.jsp.

${ }^{11}$ http://epp.eurostat.ec.europa.eu/portal/page/portal/region_cities/regional_statistics/data/main_tables. To measure regional level of competitiveness, we use the European Competitiveness Index by the University of Wales Institute. This index combines categories such as creativity, economic performance, infrastructure and accessibility, knowledge employment and education. We use the composite index from 2004 and 2006.
}

This article is protected by copyright. All rights reserved. 


\section{Estimation results}

\section{Family ownership and conservatism}

We posit in Hypothesis 1 that family-owned firms will exhibit greater conservatism and, in Hypothesis 3, that this will especially be true for those firms whose owners are married. Our measures of conservatism are firm-level sales growth, cash reserves (liquidity), use of debt (leverage), and investment. More conservative behavior is associated with lower sales growth, greater liquidity, lower leverage, and lower investment. A greater share of assets held as cash, and lower leverage, means that a firm has a cash buffer from which to meet costs or make investments without having to rely on the external credit markets for financing. A lower rate of investment combined with slower growth may also be associated with a more cautious or conservative management approach and business model.

Consistent with our hypotheses, Table 3 shows that family-owned firms, especially married-owners, exhibit significantly lower growth rates, lower investment, higher liquidity and lower leverage. An important concern is that the effect of married owners may be driven by the presence of a female owner. It is well documented that women are on average more risk averse than men in financial decisions (e.g., Levin et al., 1988; Sunden and Surette, 1998). To address this concern, all specifications include a female owner dummy. The results show that firms with a female owner behave more conservatively in terms of growth, investment, liquidity and leverage. However, the effect of married ownership remains significant.

Columns 1-3 examine sales growth. Column 1 presents the OLS results that show that family-owned firms, especially married-owners, experience lower growth rates than unrelated-owners and singleowner firms. While we cannot reject the null hypothesis that the coefficient estimates on nonmarried and unrelated-owners firms are identical, we strongly reject this hypothesis with respect to

This article is protected by copyright. All rights reserved. 
married owners. We also reject the hypothesis that family-owned firms experience the same growth rates as unrelated-owners firms. The instrumental variable (IV) estimation reveals a very similar pattern of results for the smaller sample where region information is available. The IV estimation uses a treatment effect model with a Probit model in the first stage. ${ }^{12}$ Based on the OLS estimates (Column 1) and evaluated at the sample average, firms with married owners have sales growth that are lower by $12 \%$ than sales growth by firms with unrelated owners. Based on the IV estimates (Column 3 ), this figure is $28 \%{ }^{13}$

Columns 4-6 present the results for investment. While we find no difference in investment rates between non-married-owners family firms and firms with unrelated owners, married-owners family firms have lower investment rates than all other ownership types. Evaluated at the sample average, married-owners family firms' investment rates are $9 \%$ lower than firms with unrelated owners (Column 4). The IV estimates implies a slightly higher difference of $13 \%$.

Family-owned firms rely much less on external finance, keeping greater cash reserves and using less debt. Consistent with greater conservatism (Hypothesis 3), Columns 7-12 show that married-owners family firms have higher liquidity and lower leverage ratios than all other ownership types. Evaluated at the sample average, the OLS estimates imply that married-owners family firms have a liquidity ratio that is $15 \%$ higher than of firms with unrelated owners (Column 7), and leverage ratios that are

\footnotetext{
${ }^{12}$ Table A3 in the online appendix shows the first-stage regression estimates for the IV results in Tables 3 and 4. Tables 3 and 4 also report Chi-squared test statistics (i) against the null that divorce rate is irrelevant in the first stage and (ii) against the null that it is irrelevant in the second stage. We always reject the null that our instrument is irrelevant in the first stage and always accept the null that divorce rate is irrelevant in the second stage.

${ }^{13}$ We obtain these estimates by dividing the difference in the estimated coefficients on the married and unrelated ownership dummy variables by the dependent variable sample average.
}

This article is protected by copyright. All rights reserved. 
lower by $3 \% .{ }^{14}$ The IV estimates yield a higher difference of $23 \%$ and $8 \%$ for liquidity and leverage ratios, respectively. ${ }^{15}$

[Insert Table 3 here]

\section{Family ownership and financial performance}

We posit in Hypothesis 2 that family-owned firms will exhibit higher financial performance as measured by ROA and profit margins. We posit in Hypothesis 4 that married-owners family firms will display higher measures of financial performance compared to non-married-owners family firms. We estimate the relationship between firm performance and family ownership in regression (1) examined in the previous section.

Table 4 presents the estimation results. The results show that family-owned firms, especially those with married owners, tend to outperform non-family-owned firms in terms of higher ROA and profit margins. Evaluated at the sample mean for total assets, the OLS estimates imply that a firm with married owners has an $18 \%$ ROA advantage over unrelated-owners firms (Column 1). The difference in ROA may be driven by differences in terms of conservatism. To test this, Column 2 includes our measures of conservatism: sales growth, liquidity and leverage. We also control for the number of shareholders, because shareholders are likely to vary by ownership type and their number may be correlated with financial performance. The ROA advantage of married-owners family firms remains

\footnotetext{
${ }^{14}$ While in percentage terms, leverage differences are small, in dollar terms, married-owners family firms have $\$ 51,580$ less in external debt compared to single-owner and unrelated-owners firms.

${ }^{15}$ Given the small size of many of the firms in our sample, it is also worth comparing estimates evaluated at the sample average with estimates evaluated at the sample median. To compute these latter estimates, we use the sample median values of our conservatism and financial performance measures reported in Table 1. The size of the effects is similar for all conservatism and financial performance measures, except sales growth. For instance, the OLS estimates evaluated at the sample median imply that married-owners family firms have a liquidity ratio that is $20 \%$ higher than of firms with unrelated owners, and leverage ratios that are lower by $3 \%$. However, for sales growth, the difference is lower by $24 \%$, as opposed to just $12 \%$ for the OLS estimates evaluated at the sample average.
}

This article is protected by copyright. All rights reserved. 
significant ( $9 \%$ over unrelated-owners firms), which implies that the financial advantage of married owners is not likely to be driven exclusively by varying levels of conservatism. Columns 3-4 present the IV results, which yield similar advantages for married-owners family firms ( $10 \%$ and $13 \%$, respectively).

Columns 5-8 present the analysis for profit margins. Relative to the sample average, the OLS estimates imply that married-owners family firms enjoy $12 \%$ higher margins than firms with unrelated owners (Column 6), and the IV estimates indicate $21 \%$ higher margins (Column 8 ). As in Table 3, all specifications include a female owner dummy. The presence of a female owner has a positive effect on both firm ROA and profitability, but does not alter the magnitudes of the coefficients on the married-owners dummies.

[Insert Table 4 here]

Classification of married owners. Our findings may be sensitive to measurement error in classifying family-owned firms into married versus non-married. To address this concern, we perform two types of analyses. First, we classify family-owned firms as "must be married" only if the names are in the format "Mr. and Mrs. Smith" (e.g., Mr. John Smith is one shareholder and another shareholder is Mrs. John Smith or Mrs. Mary Smith), and if the age difference between the two is less than 15 years. Second, we use information at the regional level on the percentage of married women that take the last name of their husband. We then exclude firms that are located in regions where the percentage of women who answer "Yes" to the question "Do you always use your husband's last name?" is below the sample's first quartile (68 percent). ${ }^{16}$ Tables 5 and 6 present the estimation results. The results are robust to alternative definitions of married owners.

\footnotetext{
${ }^{16}$ The source of information is the 1995 version of the Eurobarometer survey.
}

This article is protected by copyright. All rights reserved. 


\section{[Insert Tables 5 and 6 here]}

\section{Within-firm ownership changes}

Our data is a large panel of over 200,000 firms spanning 10 years. The analysis so far has relied on cross-sectional differences between firms with different ownership types. In this section we examine whether the relationship between family ownership and firm strategy and performance also holds specifically within firms that experience ownership changes. Such analysis holds constant unobservable firm characteristics that do not vary over time by differencing the dependent and independent variables. Thus, in this section, the variation used to produce our estimates comes from within-firm variation.

We explore variation in the number and nature of ownership changes across family-owned and nonfamily-owned firms using a new extraction of the Amadeus database for 2012, which provides detailed ownership information for the Amadeus universe for 2011. Ownership data are crosssectional and thus we need to rely on multiple publications of Amadeus to learn about ownership changes. Firms in our original 2007 extraction and the 2012 extraction are linked through an identifier number, which makes linking the two publications by firms straightforward. However, the shareholders of each firm do not have unique identification numbers. Therefore, in order to determine whether an owner has changed between 2007 and 2011 we need first to create a unique identification number for all owners in our data over time. Using automated algorithms and manual checks (the algorithm is available upon request) we assign a unique id to each owner. We then use this identification number to track changes in owners within firms over time. There are 82,707 firms that appear in the 2007 and 2012 publications with ownership and financial information. We use this sample to estimate the effect of ownership changes on firm performance and behavior. We say that

This article is protected by copyright. All rights reserved. 
an ownership change has occurred when the leading owner in 2007 is different from the leading owner in 2011. We focus on three types of ownership changes: from married-owners to unrelated owners, from non-married family to unrelated owners, and from unrelated owners to different unrelated owners. For other types of ownership changes, we did not find enough cases to warrant a systematic analysis of their effects. First, we compare how ownership changes in the period 20072011 are related to ownership structure in $2007.8,633$ firms changed their leading owner within this time period. Of those firms, $29 \%$ are married-owners family firms, $24 \%$ are non-married-owners family firms, and the remaining $47 \%$ are firms with unrelated owners. Next, we estimate the effect of these ownership changes on return on assets, sales growth and investment.

Table 7 presents the estimation results. Columns 1-3 present the estimation results for firms that changed ownership from married owners in 2007 to unrelated owners in 2011. In Column 1 the dependent variable is the change in growth rates between 2011 and 2007, in Column 2 the dependent variable is the change in investment between the two periods, and in Column 3 the dependent variable is the change in returns on assets for the same periods. The results are consistent with our previous findings. As firms transition away from married-owners, they become less profitable but grow faster and increase their investment. For instance, when married-owners family firms transition to unrelated owners, ROA drops by 2.9 percentage points. When we examine ownership changes from non-married family to unrelated owners in Columns 4-6, we see that sales growth and investment are unaffected, but ROA increases by 3.2 percentage points. We find similar results in Columns 7-9 when we examine ownership changes from unrelated owners to another set of unrelated owners.

Overall, these results highlight the dominant role of marital ties in driving differences in firm financial performance, growth and investment.

[Insert Table 7 here]

This article is protected by copyright. All rights reserved. 


\section{Ownership concentration}

Family owners may behave more conservatively than unrelated owners as a result of greater concentration of family assets in the firm. Risk aversion could also potentially explain the superior financial performance of family-owned firms if family owners require a larger rate of return to start a business.

Table 8 examines whether the results above are driven by ownership concentration at the family level. We restrict attention to firms owned by multiple shareholders and control for the share of equity held by the firm's dominant shareholders. ${ }^{17}$ For each firm, we aggregate equity holdings at the surname level and include this variable as a control. We expect ownership concentration at the family level to be positively related to our measures of conservatism and financial performance. However, to the extent that owners' logics (values, preferences, interpretative schemes) also matter, we expect the effect of the family ownership categories to be robust.

Columns 1-4 present the estimation results for sales growth. Ownership concentration by dominant family shareholders is as expected associated with slower growth (Column 2), but the coefficient on married family owners remains negative and significant even after controlling for equity holdings (Column 4). The coefficient on non-married family owners, however, becomes insignificant. Columns 5-8 present the estimation results for investment. The same pattern of results emerges, but, interestingly, ownership concentration at the family level is associated with greater investment, not less. Columns 9-12 present the estimation results for ROA. In that case, the effect of non-married family owners, while smaller than that of married owners, remains significant.

To summarize, the results indicate that married family ownership is an important driver of firm performance and behavior, even after controlling for ownership concentration at the family level.

\footnotetext{
${ }^{17}$ By definition, single owners own 100\% of their firm's equity. Thus, the results in Tables 3 and 4 that familyowned firms behave more conservatively and perform better than single-owner firms cannot be explained by greater ownership concentration in family-owned firms.
}

This article is protected by copyright. All rights reserved. 
The effect of non-married family ownership is less significant, especially as far as conservatism is concerned.

\section{[Insert Table 8 here]}

\section{Wage costs}

We examine a potential mechanism that may drive the observed higher profit margins and ROA of family-owned firms: wage costs. The literature suggests that, because family-owned firms provide greater employment security to their workers, they tend to have lower employment costs (Sraer and Thesmar, 2007).

Table 9 presents the estimation results. The results show that family-owned firms, especially those with married owners, have lower employment costs. Column 1 includes a dummy variable for familyowned firms. Evaluated at the sample mean, wages are $\$ 9,000$ less per employee compared to nonfamily-owned firms. Column 2 includes dummies for married- and non-married-owners family firms. The coefficient estimates on firms with married and non-married family owners are negative and statistically different from single-owner and unrelated-owners firms. Column 3 adds the female owner dummy but its coefficient is small and statistically insignificant. Column 4 presents the IV results, which are much larger in magnitude than the OLS estimates. Married-owners family firms have the lowest wages---28\% lower than unrelated-owners firms and $19 \%$ lower than firms with non-married family owners. Columns 5 and 6 show that these differences are not driven by very young firms or firms with a very small number of employees. These results mitigate the concern that lower employment costs may be driven by owner compensation: owner compensation should not greatly affect average wage as the number of employees grows larger. Overall, the results indicate

This article is protected by copyright. All rights reserved. 
that an important reason why family-owned firms, particularly married-owners family firms, have higher ROA and profit margins is that they are able to pay lower wages to their employees.

\section{[Insert Table 9 here]}

\section{Additional results and robustness tests}

In this section we discuss a number of additional findings and robustness tests to the paper's main results. The full set of results is available in the online appendix.

Firm Survival. Firms that are profitable are not likely to be terminated and conservative cash and investment policies plausibly also reduce the risk of failure. Thus, we expect family-owned firms, and especially married-owners family firms, to exhibit higher survival rates.

Table 10 examines the relationship between firm survival and ownership type. Column 1 shows that married-owners family firms are less likely to fail than non-married owners family firms (hazard ratios of 0.853 and 0.899 ) and that both married-and non-married-owners family firms are less likely to fail than unrelated-owners firms and single-owner firms. We control for firm ROA, liquidity and leverage in Column 2 and continue to find the same pattern of results. Column 3 excludes single owners. Family-owned firms are still less likely to fail than unrelated-owners firms and marriedowners family firms are still less likely to fail than non-married-owners family firms; however, the statistical significance of the latter result is diminished. Columns 4 to 7 show that our findings are, as expected, mostly driven by younger firms, which have the highest failure rates.

\section{[Insert Table 10 here]}

This article is protected by copyright. All rights reserved. 
Subsamples of firm age and size. We examine whether our main findings are robust to restricting the estimation sample by firm age and firm size. Married owners may disproportionately be firm founders, which may explain their superior performance. Restricting the sample to young firms, where all owners are likely to be founders, mitigates this concern. Table A4 in the online appendix presents the estimation results for our regressions of sales growth, investment and ROA by firm age. For each dependent variable, we estimate the regression on firms at or under the median age of 9 years and separately again on firms older than 9 years. We find that for all three dependent variables---sales growth, investment, and ROA---the impact of married family ownership is stronger in younger firms. This suggests that the effect of married owners is not mainly driven by a firm founder effect. We also split the sample based on employment size. We estimate the regressions for firms with 8 (the sample median) or fewer employees, and separately again for firms with more than 8 employees. We find that our estimates are similar in the samples of both large and small firms.

Family management. It is possible that the family ownership effect we estimate is in fact a family management effect. In Appendix Table A5, we examine whether our family ownership effects are robust to controlling for whether at least one of the managers in the firm is also a family member. In addition to controlling for the presence of a family manager, we also control for the manager's equity stake. A higher manager equity stake may lead to more conservative behavior and higher performance due to a greater portion of the managers' wealth being dependent on the firm. We find that our results are robust in all cases. Interestingly, while we find, as expected, that a greater manager's equity stake also leads to more conservative behavior, we do not find that the presence of a family manager does so. We find that a family manager is associated with higher ROA, profit margin and sales growth, and no effect on liquidity, leverage, and investment.

Differential tax treatment of family firms. In Appendix Table A6 regressions, we also examine whether the higher ROA and profitability of family-owned firms may be due to differences in tax rates. We control for a country's difference in the top personal and top corporate income tax rates,

This article is protected by copyright. All rights reserved. 
to see whether the family ownership effect on ROA and profits is due to greater ability to avoid paying the higher tax rate. We find that, when the personal tax rate is higher than the corporate tax rate, firms have higher profit margins, though the effect is not statistically significant. The family ownership effect is unchanged by the inclusion of the tax rate difference control.

\section{Discussion}

The literature on the "family effect" on firm performance has yielded mixed or conflicting results, with some studies suggesting a positive effect and other studies suggesting a negative effect. An important reason for these conflicting results has been the heterogeneity of datasets, performance measures and empirical approaches adopted. Researchers have used different definitions of family firms, have often aggregated firms run by different generations of family owners, and have generally not distinguished between lone, or single, owners and broader family involvement in a business. In addition, several performance measures have been used, but these measures (e.g., profitability versus growth) may be differentially affected by owners' strategic orientations.

The present paper helps address these issues. We examine how the social context of ownership affects firm strategy and performance. We distinguish among firms owned by multiple unrelated individuals, firms owned by multiple family-related individuals ("family owners"), and firms owned by a single individual ("single owner"). Within family-owned firms, we further distinguish between firms that are predominantly owned by a married couple and firms that are predominantly owned by other types of family members, such as parents and children or siblings.

Drawing on embeddedness theory and the institutional logics perspective, we argue that family owners will predominantly be concerned with providing stable, secure income to family members. Married owners, in particular, may come to perceive their firm as a legacy or bequest to their children. This 'familiar logic' of family owners can be a source of comparative advantage---it can

This article is protected by copyright. All rights reserved. 
motivate family owners to work hard---but can also discourage risk taking, thus dampening growth. Consistent with these hypotheses, we find that family-owned firms earn significantly higher returns on assets and higher profit margins than non-family-owned firms, and also exhibit higher survival rates. These effects are partly driven by the ability or willingness of family owners to keep cash within the firm and to keep operating costs low (in particular wage costs). However, family ownership is also associated with lower investment and slower growth, especially when firms are young. Thus, the familiar logic of family owners appears to bring with it both costs and benefits.

The results for conservatism and to a lesser extent those for financial performance are driven by firms whose two largest shareholders are married. In particular, the effect of non-married family owners on conservatism becomes insignificant when ownership concentration is controlled for and in the ownership change regressions. This indicates that Hypothesis 1 does not hold independent of Hypothesis 3. (By contrast, the effect of non-married family owners on financial performance is robust.) There are significant differences in how different types of family owners manage their firms. Thus, when theorizing on "family" effects in family-owned firms, finer distinctions among different types of owners and performance measures may be necessary.

By highlighting the importance of marital ties, the paper underscores the role of rituals and symbols in the emergence of institutional logics. Institutional logics researchers have identified a number of factors that can bring about changes in logics, such as cultural factors (Lounsbury and Crumley, 2007), powerful actors such as the state or the profession (Garud et al. 2002; Greenwood et al., 2002; Lounsbury, 2002), and key individuals (Thornton et al., 2012). Rituals and symbols can also facilitate the emergence of new logics. As Friedland and Alford (1991: 232) note, institutions are not just "patterns of activity through which humans conduct their material life in time and space" but also "symbolic systems through which they categorize that activity and infuse it with meaning." Our results suggest that marriage is a ritual that induces people to re-evaluate their priorities and social

This article is protected by copyright. All rights reserved. 
identities. It marks the transition between the entrepreneurial, growth-oriented logic of lone owners to the more conservative logic of family owners.

The present paper also informs agency-theoretic views of the firm. We find little support for the argument that family-owned firms perform better and are more likely to survive because there are fewer conflicts of interest between owners or better monitoring between owners and managers. Indeed, family-owned firms perform better in terms of profits, returns and survival than firms owned by a single individual, where ownership and managerial responsibilities often coincide.

The present paper also complements existing research on family firms by providing better coverage of small firms than usually available. Most firms in our dataset are very small---the median firm in our sample has just 8 employees, and the 90th percentile firm has 44 . For the owners of these very small firms, providing a stable, secure income to other family members is likely to be a major concern. Large publicly listed family firms, by contrast, are likely to be owned by wealthy individuals who may not place the same value on income security as small business owners. Thus, research focusing on large, often public family firms may have downplayed some important motivations of family owners.

Our analysis controls for several potential confounding factors. It is possible, for instance, that family owners and especially married ones behave more conservatively than other types of owners because their wealth is less diversified. We find that ownership concentration computed at the family level is indeed associated with conservatism; however, the effect of married ownership remains strong. This suggests that it is not just ownership or wealth concentration that matters, but also who the owners are, and what their priorities are (Fiss and Zajac, 2004; Yin and Zajac, 2004; Miller et al., 2010).

Gender differences in ability or risk-taking may also confound our results. Female owners may at the same time be more capable and more risk averse than their male counterparts. Our results are robust to controlling for female ownership. Moreover, married owners may be drawn

This article is protected by copyright. All rights reserved. 
disproportionately from the population of firm founders, and founders may on average be abler, and perhaps also more risk-averse, than second- or third-generation owners. We mitigate this concern by showing that our results also hold in a subsample of young firms, where all owners are likely to be firm founders.

A limitation of our analysis is that we classify owners as married or not married using empirical strategies based on data on owners' surnames, sex, age, titles, country-level propensity of married women to assume the husband's surname, etcetera. These strategies are imperfect and we cannot exclude misclassification errors (which, however, would bias our estimates against finding any differences between ownership structures). Collecting more detailed personal data on owners is an important task to make progress in this area.

Another limitation of our analysis concerns the extent to which our results can be interpreted causally. One interpretation of our results is that ownership by a married couple causes more conservative management strategies and other differences in strategic behavior that leads to higher financial performance and survival rates. Another interpretation is that married couples select business opportunities that are less risky and have higher profit potential. Our instrumental variables estimation, and to some extent our within firm ownership change analysis, suggests that the selection interpretation is not the whole story, although it likely explains some of the identified correlation between married family ownership and firm behavior. Under either interpretation, our results suggest that married couples disproportionately care about owning less risky firms and ones that exhibit higher performance, whether they actively cause these outcomes or simply choose to start firms with these underlying characteristics.

\section{Conclusion}

This article is protected by copyright. All rights reserved. 
Family firms operate at the intersection of two fundamental human spheres: the family and the business. Despite the growing interest in family firms, very little is known about the family side of the equation. Using a large panel of private European firms, this paper explores how the social context of ownership---the types of affective ties that exist between shareholders---influence corporate strategy and performance. We show that family owners select and manage very different types of firms relative to single individuals or unrelated owners. Specifically, we find evidence of a trade-off to family ownership, in which family-owned firms are managed more conservatively, increasing profits, liquidity and survival, but diminishing investment and growth. This trade-off can be seen as the manifestation of a 'familiar logic'---a logic that enhances commitment to the firm by family owners, but also prioritizes the preservation of wealth over growth.

The familiar logic of family owners is most pronounced among married owners. As stressed by embeddedness theorists, logics vary with social context, depending on the nature and strength of social ties (Granovetter, 1973; Uzzi, 1996, 1997). Married owners may both work harder and behave more conservatively than other types of family and non-family shareholders because they are more concerned with the welfare of future generations, and therefore with the long-term performance and survival of the firm. These motivations are likely to be most important for small business owners, on which our analysis focuses. Overall, our results suggest that it may be misleading to talk about "family effects" on firm strategy and performance. The strength of affective ties varies also within the family. Deconstructing the concept of "family" in family-owned firms may enable a better understanding of how these important institutions operate.

ACKNOWLEDGEMENTS: We thank two anonymous referees and the Editor, Constance Helfat, for very constructive comments that substantially improved the paper. We also grateful to Mark Schankerman, William Schulze, David Sraer, Margarita Tsoutroura, Belen Villalonga, seminar participants at several universities, and especially Ashish Arora for helpful comments and suggestions. The analysis and conclusions presented in this paper are 
those of the authors and do not necessarily indicate concurrence by members of the Federal Reserve Board of Governors or its staff.

\section{References}

Anderson RC, Reeb DM. 2003. Founding-family ownership and firm performance: evidence from the S\&P 500. Journal of Finance 58(3): 1301-1328.

Bantel KA, Jackson SE. 1989. Top management and innovations in banking: does the composition of the top team make a difference? Strategic Management Journal 10(S1): 107-124.

Beatty R, Zajac E. 1994. Managerial incentives, monitoring, and risk bearing: a study of executive compensation, ownership, and board structure in initial public offerings. Administrative Science Quarterly 39(2): 313-335.

Berrone P, Cruz C, Gomez-Mejia LR. 2012. Socioemotional wealth in family firms: theoretical dimensions, assessment approaches, and agenda for future research. Family Business Review 25(3): 258-279.

Bertrand M, Schoar A. 2006. The role of family in family firms. Journal of Economic Perspectives 20(2): 73-96.

Block JH. 2012. R\&D investments in family and founder firms: an agency perspective. Journal of Business Venturing 27(2): 248-265.

Bloom N, Van Reenen J. 2007. Measuring and explaining management practices across firms and countries. Quarterly Journal of Economics 122(4): 1351-1408.

Carpenter M. 2002. The implications of strategy and social context for the relationship between top management team heterogeneity and firm performance. Strategic Management Journal 23(3): 275284.

Chrisman JJ, Chua JH, Steier L. 2005. Sources and consequences of distinctive familiness: an introduction. Entrepreneurship Theory and Practice 29(3): 237-247.

Chua JH, Chrisman JJ, Sharma P. 1999. Defining the family business by behavior. Entrepreneurship Theory and Practice 23(4): 19-39.

Chung C-N, Luo XR. 2013. Leadership succession and firm performance in an emerging economy: successor origin, relational embeddedness, and legitimacy. Strategic Management Journal 34(3): 338-357.

Colli A. 2002. The History of Family Business, 1850-2000. Cambridge University Press: Cambridge.

Dawkins R. 2006. The Selfish Gene. Oxford University Press: Oxford.

Dyer WG Jr. 2006. Examining the "family effect" on firm performance. Family Business Review 19(4): 253-273.

Eisenhardt KM. 1989. Agency theory: an assessment and review. Academy of Management Review 14(1): 57-74.

This article is protected by copyright. All rights reserved. 
Eller JD. 2009. Cultural Anthropology: Global Forces, Local Lives. Routledge: New York.

Feldman ER, Amit R, Villalonga B. 2014. Corporate divestitures and family control. Strategic Management Journal forthcoming.

Fiss PC, Zajac EJ. 2004. The diffusion of ideas over contested terrain: the (non) adoption of a shareholder value orientation among German firms. Administrative Science Quarterly 49(4): 501534.

Friedland R, Alford RR. 1991. Bringing society back in: symbols, practices, and institutional contradictions. In The New Institutionalism in Organizational Analysis, Powell WW, DiMaggio PJ (eds). University of Chicago: Chicago, IL: 232-265.

Gallo MA, Tapies J, Cappuyns K. 2004. Comparison of family and nonfamily business: financial logic and personal preferences. Family Business Review 17(4): 303-318.

Garud R, Jain S, Kumaraswamy A. 2002. Institutional entrepreneurship in the sponsorship of common technological standards: the case of Sun Microsystems and Java. Academy of Management Journal 45(1): 196-214.

Gersick KE, Davis JA, Hampton MM, Lansberg I. 1997. Generation to Generation: Life Cycles of the Family Business. Harvard Business School Press: Boston, MA.

Gomez-Mejia LR, Nunez-Nickel M, Gutierrez I. 2001. The role of family ties in agency contracts. Academy of Management Journal 44(1): 81-95.

Gomez-Mejia LR, Takacs Haynes K, Nunez-Nickel M, Jacobson KJL, Moyano-Fuentes J. 2007.

Socioemotional wealth and business risks in family-controlled firms: evidence from Spanish olive oil mills. Administrative Science Quarterly 52(1): 106-137.

Granovetter M. 1973. The strength of weak ties. American Journal of Sociology 78(6): 1360-1380.

Granovetter M. 1985. Economic action and social structure: the problem of embeddedness. American Journal of Sociology 91(3): 481-510.

Greenwood R, Deephouse DL, Xiao Li S. 2007. Ownership and performance of professional service firms. Organization Studies 28(2): 219-238.

Greenwood R, Diaz AM, Xiao Li S, Cespedes Lorente J. 2010. The multiplicity of institutional logics and the heterogeneity of organizational responses. Organization Science 21(2): 521-539.

Greenwood R, Suddaby R, Hinings CR. 2002. Theorizing change: The role of professional associations in the transformation of institutional fields. Academy of Management Journal 45(1): 58-80.

Jensen MC, Meckling W. 1976. Theory of the firm: managerial behavior, agency costs and ownership structure. Journal of Financial Economics 3(4): 305-360.

Karra N, Tracey P, Phillips N. 2006. Altruism and agency in the family firm: exploring the role of family, kinship, and ethnicity. Entrepreneurship Theory and Practice 30(6): 861-877.

Leach P. 2007. Family Businesses: The Essentials. Profile Books: London.

Le Breton-Miller I, Miller D. 2009. Agency vs. stewardship in public family firms: a social embeddedness reconciliation. Entrepreneurship Theory and Practice 33(6): 1169-1191.

This article is protected by copyright. All rights reserved. 
Le Breton-Miller I, Miller D, Lester RH. 2011. Stewardship or agency? a social embeddedness reconciliation of conduct and performance in public family businesses. Organization Science 22(3): 704-721.

Levin IP, Snyder MA, Chapman DP. The interaction of experiential and situational factors and gender in a simulated risky decision-making task. Journal of Psychology 122(2): 173-181.

Levi-Strauss C. 1969. The Elementary Structures of Kinship. Beacon Press: Boston, MA.

Lounsbury M. 2002. Institutional transformation and status mobility: the professionalization of the field of finance. Academy of Management Journal 45(1): 255-266.

Lounsbury M. 2007. A tale of two cities: competing logics and practice variation in the professionalizing of mutual funds. Academy of Management Journal 50(2): 289-307.

Lounsbury M, Crumley ET. 2007. New practice creation: an institutional perspective on innovation. Organization Studies 28(7): 993-1012.

Miller D, Le Breton-Miller I, Lester RH. 2010, Family ownership and acquisition behavior in publiclytraded companies. Strategic Management Journal 31(2): 201-223.

Miller D, Le Breton-Miller I, Lester RH. 2011. Family and lone founder ownership and strategic behaviour: social context, identity, and institutional logics. Journal of Management Studies 48(1): 125.

Miller D, Le Breton-Miller I, Lester RH. 2013. Family firm governance, strategic conformity, and performance: institutional vs. strategic perspectives. Organization Science 24(1): 189-209.

Miller D, Le Breton-Miller I, Lester RH, Cannella AAJr. 2007. Are family firms really superior performers? Journal of Corporate Finance 13(5): 829-858.

Miller D, Le Breton-Miller I, Scholnick B. 2008. Stewardship vs. stagnation: an empirical comparison of small family and non-family businesses. Journal of Management Studies 45(1): 51-78.

Miller D, Minichilli A, Corbetta G. 2013. Is family leadership always beneficial? Strategic Management Journal 34(5): 553-571.

Minichilli A, Corbetta G, MacMillan IC. 2010. Top management teams in family-controlled companies: 'familiness', 'faultiness', and their impact on financial performance. Journal of Management Studies 47(2): 205-222.

Mishra CS, McConaughy DL. 1999. Founding family control and capital structure: the risk of loss of control and the aversion to debt. Entrepreneurship Theory and Practice 23(4): 53-65.

Ocasio W. 1997. Towards an attention-based view of the firm. Strategic Management Journal 18(S1): 187-206.

Parker SC. 2008. Entrepreneurship among married couples in the United States: a simultaneous probit approach. Labour Economics 15(3): 459-481.

Patel PC, Chrisman JJ. 2014. Risk abatement as a strategy for R\&D investments in family firms. Strategic Management Journal 35(4): 617-627.

Peredo AM. 2003. Nothing thicker than blood: commentary on "Help one another, use one another: toward an anthropology of family business." Entrepreneurship Theory and Practice 27(4): 397-400.

This article is protected by copyright. All rights reserved. 
Perez-Gonzalez F. 2006. Inherited control and firm performance. American Economic Review 96(5): 1559-1588.

Rumelt RP. 1991. How much does industry matter? Strategic Management Journal 12(3): 167-185.

Sraer D, Thesmar D. 2007. The performance and behavior of family-owned firms: evidence from the French stock market. Journal of the European Economic Association 5(4): 709-751.

Sunden AE, Surette BJ. 1998. Gender differences in the allocation of assets in retirement savings plans. American Economic Review (Papers and Proceedings) 88(2): 207-211.

Stewart A. 2003. Help one another, use one another: toward an anthropology of family business. Entrepreneurship Theory and Practice 27(4): 383-396.

Thornton PH. 2004. Markets from Culture: Institutional Logics and Organizational Decisions in Higher Education Publishing. Stanford University Press: Stanford, CA.

Thornton PH, Ocasio W. 1999. Institutional logics and the historical contingency of power in organizations: executive succession in the higher education publishing industry, 1958-1990. American Journal of Sociology 105(3): 801-843.

Thornton PH, Ocasio W. 2008. Institutional logics. In The SAGE Handbook of Organizational Institutionalism, Greenwood R, Oliver C, Sahlin K, Suddaby R (eds). Sage: Los Angeles, CA: 99-129.

Thornton PH, Ocasio W, Lounsbury M. 2012. Institutional Logics Perspective: A New Approach to Culture, Structure, and Process. Oxford University Press: Oxford.

Uzzi B. 1996. The sources and consequences of embeddedness for the economic performance of organizations: the network effect. American Sociological Review 61(4): 674--698.

Uzzi B. 1997. Social structure and competition in interfirm networks: the paradox of embeddedness. Administrative Science Quarterly 42(1): 35--68.

Uzzi B, Gillespie JJ. 2002. Knowledge spillover in corporate financing networks: embeddedness and the firm's debt performance. Strategic Management Journal 23(7): 595-618.

Villalonga B, Amit R. 2006. How do family ownership, control and management affect firm value? Journal of Financial Economics 80(2): 385-417.

Walter SG, Heinrichs S, Walter A. 2014. Parent hostility and spin-out performance. Strategic Management Journal 35(13): 2031-2042.

Westphal JD, Zajac EJ. 1994. Substance and symbolism in CEO's long-term incentive plans. Administrative Science Quarterly 39(3): 367--390.

Wiseman RM, Gomez-Mejia LR. 1998. A behavioral agency model of managerial risk taking. Academy of Management Review 23(1): 133-153.

Wong YC. 1986. Entrepreneurship, marriage, and earnings. Review of Economics and Statistics 68(4): 693-699.

Xia F, Walker G. 2015. How much does owner type matter for firm performance? Manufacturing firms in China 1998-2007. Strategic Management Journal 36(4): 576-585.

Yin X, Zajac E. 2004. The strategy/governance fit relationship: theory and evidence in franchising arrangements. Strategic Management Journal 25(4): 365-383.

This article is protected by copyright. All rights reserved. 
Table 1. Summary Statistics

\begin{tabular}{|c|c|c|c|c|c|c|c|}
\hline \multirow[b]{2}{*}{ Variable } & \multirow[b]{2}{*}{ Obs. } & \multirow[b]{2}{*}{ Firms } & \multirow[b]{2}{*}{ Mean } & \multirow[b]{2}{*}{ Std. Dev. } & \multicolumn{3}{|c|}{ Distribution } \\
\hline & & & & & $10^{\text {th }}$ & $50^{\text {th }}$ & $90^{\text {th }}$ \\
\hline Dummy for Family Owners & $1,258,172$ & 228,253 & 0.247 & 0.431 & 0 & 0 & 1 \\
\hline Dummy for Married Family Owners & $1,258,172$ & 228,253 & 0.094 & 0.292 & 0 & 0 & 1 \\
\hline Dummy for Non-Married Family Owners & $1,258,172$ & 228,253 & 0.152 & 0.359 & 0 & 0 & 1 \\
\hline Dummy for Unrelated Owners & $1,258,172$ & 228,253 & 0.421 & 0.494 & 0 & 0 & 1 \\
\hline Dummy for Single Owner & $1,258,172$ & 228,253 & 0.333 & 0.471 & 0 & 0 & 1 \\
\hline Dummy for Female Owner & $1,258,172$ & 228,253 & 0.321 & 0.467 & 0 & 0 & 1 \\
\hline es Growth & $1,244,008$ & 226,723 & 0.200 & 0.538 & -0.198 & 0.101 & 0.626 \\
\hline Liquidity & $1,078,368$ & 217,003 & 0.286 & 0.569 & 0.038 & 0.212 & 0.655 \\
\hline yerage & $1,230,284$ & 227,449 & 0.749 & 0.341 & 0.383 & 0.753 & 0.990 \\
\hline nvestment & $1,258,012$ & 228,233 & 0.137 & 0.401 & -0.222 & 0.101 & 0.536 \\
\hline Returns on Assets & $1,254,515$ & 227,758 & 0.132 & 0.210 & -0.003 & 0.107 & 0.317 \\
\hline Profit Margin & $1,256,696$ & 228,216 & 0.076 & 0.140 & -0.001 & 0.056 & 0.194 \\
\hline ets $(\$, ' 000)$ & $1,258,172$ & 228,253 & 2,579 & 43,882 & 91 & 457 & 3,892 \\
\hline Sales $(\$, ' 000)$ & $1,258,172$ & 228,253 & 3,740 & 53,126 & 199 & 842 & 6,104 \\
\hline BITDA $(\$, ' 000)$ & $1,258,164$ & 228,252 & 157 & 2,657 & -13 & 31 & 294 \\
\hline Firm Age & $1,258,172$ & 228,253 & 12 & 23.2 & 2 & 9 & 25 \\
\hline ear of Incorporation & $1,258,172$ & 228,253 & 1990 & 9.4 & 1978 & 1993 & 2000 \\
\hline nber of Employees & 750,815 & 180,979 & 24 & 111 & 2 & 8 & 44 \\
\hline Wage per Employee $(\$, 000)$ & 748,159 & 180,138 & 36 & 888 & 14 & 27 & 51 \\
\hline Number of Shareholders & $1,258,172$ & 228,253 & 2 & 1 & 1 & 2 & 3 \\
\hline Region Divorce Rate & $1,109,312$ & 201,653 & 0.069 & 0.036 & 0.022 & 0.065 & 0.121 \\
\hline
\end{tabular}

Notes: This table provides summary statistics for the main variables used in the econometric analysis. Return on Assets is EBITDA over Assets. Profit Margin is EBITDA over Sales. Sales Growth is the annual change in log sales. Investment is the annual change in log total assets. Firm Age is years from date of incorporation. Liquidity is cash over Assets. Leverage is the sum of current and non-current liabilities over Assets. For detailed definitions of ownership types, Single Owner, Family Owners, Married Family Owners, Non-Married Family Owners and Unrelated Owners, please see Section 3 of the paper.

This article is protected by copyright. All rights reserved. 
Table 3. Family Ownership and Conservatism

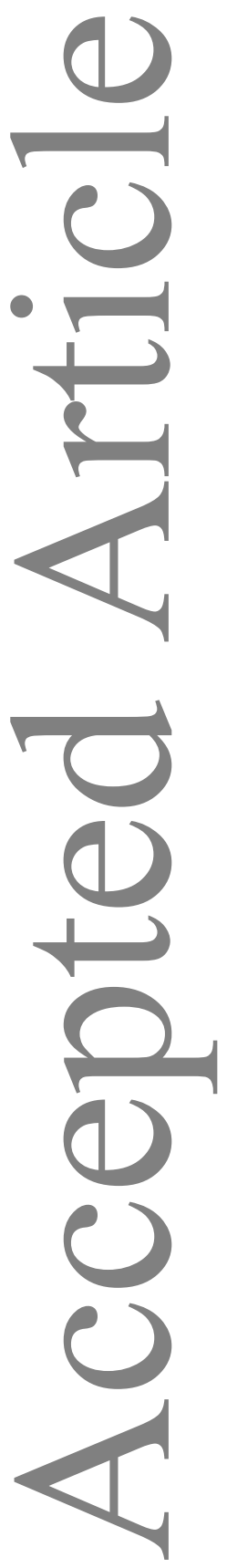

\begin{tabular}{|c|c|c|c|c|c|c|c|c|c|c|c|c|}
\hline & $(1)$ & $(2)$ & (3) & (4) & $(5)$ & $(6)$ & (7) & $(8)$ & (9) & $(10)$ & $(11)$ & (12) \\
\hline \multirow[t]{3}{*}{ Dependent variable: } & \multicolumn{3}{|c|}{ Sales growth } & \multicolumn{3}{|c|}{ Investment } & \multicolumn{3}{|c|}{ Liquidity } & \multicolumn{3}{|c|}{ Leverage } \\
\hline & \multirow{2}{*}{$\begin{array}{c}\begin{array}{c}\text { Full } \\
\text { sample }\end{array} \\
\text { OLS }\end{array}$} & \multicolumn{2}{|c|}{ IV sample } & \multirow{2}{*}{$\begin{array}{c}\begin{array}{c}\text { Full } \\
\text { sample }\end{array} \\
\text { OLS } \\
\end{array}$} & \multicolumn{2}{|c|}{ IV sample } & \multirow{2}{*}{$\begin{array}{c}\begin{array}{c}\text { Full } \\
\text { sample }\end{array} \\
\text { OLS }\end{array}$} & \multicolumn{2}{|c|}{ IV sample } & \multirow{2}{*}{$\begin{array}{c}\begin{array}{c}\text { Full } \\
\text { sample }\end{array} \\
\text { OLS } \\
\end{array}$} & \multicolumn{2}{|c|}{ IV sample } \\
\hline & & OLS & IV & & OLS & IV & & OLS & IV & & OLS & IV \\
\hline \multicolumn{13}{|l|}{ (a) Dummy for Married Family } \\
\hline $\begin{array}{l}\text { Owners } \\
\text { (b) Dummy for Non-Married }\end{array}$ & $\begin{array}{c}-0.028^{* *} \\
(0.002)\end{array}$ & $\begin{array}{c}-0.041^{* *} \\
(0.004)\end{array}$ & $\begin{array}{c}-0.060^{* *} \\
(0.007)\end{array}$ & $\begin{array}{c}-0.016^{* *} \\
(0.001)\end{array}$ & $\begin{array}{c}-0.014^{* *} \\
(0.003)\end{array}$ & $\begin{array}{c}-0.018^{* *} \\
(0.005)\end{array}$ & $\begin{array}{c}0.035^{* *} \\
(0.003)\end{array}$ & $\begin{array}{c}0.083^{* *} \\
(0.006)\end{array}$ & $\begin{array}{c}0.100^{* *} \\
(0.008)\end{array}$ & $\begin{array}{c}-0.023^{* *} \\
(0.002)\end{array}$ & $\begin{array}{c}-0.034 * * \\
(0.005)\end{array}$ & $\begin{array}{c}-0.065^{* *} \\
(0.007)\end{array}$ \\
\hline Family Owners & $\begin{array}{c}-0.006^{* *} \\
(0.002)\end{array}$ & $\begin{array}{c}-0.019^{* *} \\
(0.004)\end{array}$ & $\begin{array}{c}-0.018^{* *} \\
(0.004)\end{array}$ & $\begin{array}{c}-0.004^{* *} \\
(0.001)\end{array}$ & $\begin{array}{c}-0.006^{* *} \\
(0.002)\end{array}$ & $\begin{array}{c}-0.006^{* *} \\
(0.002)\end{array}$ & $\begin{array}{c}0.009 * * \\
(0.002)\end{array}$ & $\begin{array}{c}0.038^{* *} \\
(0.005)\end{array}$ & $\begin{array}{c}0.038^{* *} \\
(0.006)\end{array}$ & $\begin{array}{c}-0.019^{* *} \\
(0.002)\end{array}$ & $\begin{array}{c}-0.028^{* *} \\
(0.005)\end{array}$ & $\begin{array}{c}-0.028^{* *} \\
(0.005)\end{array}$ \\
\hline (c) Dummy for Unrelated Owners & $\begin{array}{c}-0.004 * * \\
(0.001)\end{array}$ & Base & Base & $\begin{array}{c}-0.004 * * \\
(0.001)\end{array}$ & Base & Base & $\begin{array}{c}-0.007^{* *} \\
(0.001)\end{array}$ & Base & Base & $\begin{array}{l}-0.002 \\
(0.002)\end{array}$ & Base & Base \\
\hline Dummy for Female Owner & $\begin{array}{c}-0.018^{* *} \\
(0.001)\end{array}$ & $\begin{array}{c}-0.024^{* *} \\
(0.003)\end{array}$ & $\begin{array}{c}-0.023^{* *} \\
(0.003)\end{array}$ & $\begin{array}{c}-0.014^{* *} \\
(0.001)\end{array}$ & $\begin{array}{c}-0.014^{* *} \\
(0.002)\end{array}$ & $\begin{array}{c}-0.014^{* *} \\
(0.002)\end{array}$ & $\begin{array}{c}0.015^{* *} \\
(0.001)\end{array}$ & $\begin{array}{c}0.034 * * \\
(0.005)\end{array}$ & $\begin{array}{c}0.033^{* *} \\
(0.005)\end{array}$ & $\begin{array}{c}-0.011^{* *} \\
(0.001)\end{array}$ & $\begin{array}{c}-0.010^{* *} \\
(0.004)\end{array}$ & $\begin{array}{c}-0.010^{* *} \\
(0.004)\end{array}$ \\
\hline $\ln (\text { Sales })_{\mathrm{t}-1}$ & $\begin{array}{c}-0.095 * * \\
(0.001)\end{array}$ & $\begin{array}{c}-0.098^{* *} \\
(0.002)\end{array}$ & $\begin{array}{c}-0.099 * * \\
(0.002)\end{array}$ & $\begin{array}{c}-0.041^{* *} \\
(0.001)\end{array}$ & $\begin{array}{c}-0.043^{* *} \\
(0.001)\end{array}$ & $\begin{array}{c}-0.043 * * \\
(0.001)\end{array}$ & $\begin{array}{c}-0.035^{* *} \\
(0.001)\end{array}$ & $\begin{array}{c}-0.065^{* *} \\
(0.002)\end{array}$ & $\begin{array}{c}-0.065^{* *} \\
(0.002)\end{array}$ & $\begin{array}{c}-0.020^{* *} \\
(0.001)\end{array}$ & $\begin{array}{c}-0.028 * * \\
(0.002)\end{array}$ & $\begin{array}{c}-0.028^{* *} \\
(0.002)\end{array}$ \\
\hline Firm Age $(\times 10)$ & $\begin{array}{c}-0.042 * * \\
(0.001)\end{array}$ & $\begin{array}{c}-0.121^{* *} \\
(0.002)\end{array}$ & $\begin{array}{c}-0.121^{* *} \\
(0.002)\end{array}$ & $\begin{array}{c}-0.027 * * \\
(0.001)\end{array}$ & $\begin{array}{c}-0.065^{* *} \\
(0.001)\end{array}$ & $\begin{array}{c}-0.065^{* *} \\
(0.001)\end{array}$ & $\begin{array}{c}-0.010^{* *} \\
(0.001)\end{array}$ & $\begin{array}{c}-0.046^{* *} \\
(0.003)\end{array}$ & $\begin{array}{c}-0.050^{* *} \\
(0.003)\end{array}$ & $\begin{array}{c}-0.049 * * \\
(0.001)\end{array}$ & $\begin{array}{c}-0.078^{* *} \\
(0.003)\end{array}$ & $\begin{array}{c}-0.078^{* *} \\
(0.003)\end{array}$ \\
\hline \multicolumn{13}{|l|}{$\begin{array}{l}\text { First stage (Dummy for Married } \\
\text { Owners): }\end{array}$} \\
\hline Region Divorce Rate & & & $\begin{array}{c}-1.630^{* *} \\
(0.328)\end{array}$ & & & $\begin{array}{c}-1.623 * * \\
(0.327)\end{array}$ & & & $\begin{array}{c}-1.611^{* *} \\
(0.339)\end{array}$ & & & $\begin{array}{c}-1.640^{* *} \\
(0.327)\end{array}$ \\
\hline $\begin{array}{l}\chi^{2} \text {-statistic against the null that } \\
\text { divorce rate is irrelevant in the first- } \\
\text { stage: }\end{array}$ & & & $35.33^{* *}$ & & & $36.12^{* *}$ & & & $34.89^{* *}$ & & & $36.59^{* *}$ \\
\hline Three-digit SIC code dummies & Yes & Yes & Yes & Yes & Yes & Yes & Yes & Yes & Yes & Yes & Yes & Yes \\
\hline Country dummies & Yes & Yes & Yes & Yes & Yes & Yes & Yes & Yes & Yes & Yes & Yes & Yes \\
\hline Year dummies & Yes & Yes & Yes & Yes & Yes & Yes & Yes & Yes & Yes & Yes & Yes & Yes \\
\hline Region controls & No & Yes & Yes & No & Yes & Yes & No & Yes & Yes & No & Yes & Yes \\
\hline $\begin{array}{l}\text { Hypotheses testing (p-value }) \text { : } \\
(\mathrm{a})=(\mathrm{b})\end{array}$ & $\mathrm{p}<0.01$ & $\mathrm{p}<0.01$ & $\mathrm{p}<0.01$ & $\mathrm{p}<0.01$ & $\mathrm{p}<0.01$ & $\mathrm{p}<0.01$ & $\mathrm{p}<0.01$ & $\mathrm{p}<0.01$ & $\mathrm{p}<0.01$ & $\mathrm{p}>0.10$ & $\mathrm{p}>0.10$ & $\mathrm{p}<0.01$ \\
\hline$(b)=(c)$ & $\mathrm{p}=0.07$ & $\mathrm{p}<0.01$ & $\mathrm{p}<0.01$ & $\mathrm{p}>0.10$ & $\mathrm{p}<0.01$ & $\mathrm{p}>0.10$ & $\mathrm{p}<0.01$ & $\mathrm{p}<0.01$ & $\mathrm{p}<0.01$ & $\mathrm{p}<0.01$ & $\mathrm{p}<0.01$ & $\mathrm{p}<0.01$ \\
\hline$(\mathrm{a})=(\mathrm{c})$ & $\mathrm{p}<0.01$ & $\mathrm{p}<0.01$ & $\mathrm{p}<0.01$ & $\mathrm{p}<0.01$ & $\mathrm{p}<0.01$ & $\mathrm{p}<0.01$ & $\mathrm{p}<0.01$ & $\mathrm{p}<0.01$ & $\mathrm{p}<0.01$ & $\mathrm{p}<0.01$ & $\mathrm{p}<0.01$ & $\mathrm{p}<0.01$ \\
\hline
\end{tabular}

$\chi^{2}$-statistic against the null that divorce rate is irrelevant in the second stage: 
Table 4. Family Ownership and Financial Performance

\begin{tabular}{|c|c|c|c|c|c|c|c|c|}
\hline & $(1)$ & $(2)$ & (3) & (4) & $(5)$ & $(6)$ & (7) & $(8)$ \\
\hline \multirow[t]{3}{*}{ Dependent variable: } & \multicolumn{4}{|c|}{ Return on Assets } & \multicolumn{4}{|c|}{ Profit Margin } \\
\hline & \multicolumn{2}{|c|}{ Full sample } & \multicolumn{2}{|c|}{ IV sample } & \multicolumn{2}{|c|}{ Full sample } & \multicolumn{2}{|c|}{ IV sample } \\
\hline & OLS & OLS & OLS & IV & OLS & OLS & OLS & IV \\
\hline $\begin{array}{l}\text { (a) Dummy for Married Family } \\
\text { Owners } \\
\text { (b) Dummy for Non-Married Famil }\end{array}$ & $\begin{array}{c}0.025^{* *} \\
(0.001)\end{array}$ & $\begin{array}{c}0.021 * * \\
(0.001)\end{array}$ & $\begin{array}{c}0.019^{* *} \\
(0.002)\end{array}$ & $\begin{array}{c}0.024^{* *} \\
(0.003)\end{array}$ & $\begin{array}{c}0.014 * * \\
(0.001)\end{array}$ & $\begin{array}{c}0.011^{* *} \\
(0.001)\end{array}$ & $\begin{array}{c}0.013 * * \\
(0.002)\end{array}$ & $\begin{array}{c}0.019^{* *} \\
(0.002)\end{array}$ \\
\hline Owners & $\begin{array}{c}0.006^{* *} \\
(0.001)\end{array}$ & $\begin{array}{c}0.008^{* *} \\
(0.001)\end{array}$ & $\begin{array}{l}0.005^{*} \\
(0.002)\end{array}$ & $\begin{array}{c}0.005^{* *} \\
(0.002)\end{array}$ & $\begin{array}{c}0.006^{* *} \\
(0.001)\end{array}$ & $\begin{array}{c}0.006^{* *} \\
(0.001)\end{array}$ & $\begin{array}{c}0.008^{* *} \\
(0.002)\end{array}$ & $\begin{array}{c}0.008^{* *} \\
(0.002)\end{array}$ \\
\hline (c) Dummy for Unrelated Owners & $\begin{array}{c}0.001 \\
(0.001)\end{array}$ & $\begin{array}{c}0.009^{* *} \\
(0.001)\end{array}$ & Base & Base & $\begin{array}{l}-0.001 \\
(0.001)\end{array}$ & $\begin{array}{l}0.002^{*} \\
(0.001)\end{array}$ & Base & Base \\
\hline Dummy for Female Owner & $\begin{array}{c}0.008^{* *} \\
(0.001)\end{array}$ & $\begin{array}{c}0.003^{* *} \\
(0.001)\end{array}$ & $\begin{array}{c}0.012^{* *} \\
(0.002)\end{array}$ & $\begin{array}{c}0.011^{* *} \\
(0.002)\end{array}$ & $\begin{array}{c}0.003^{* *} \\
(0.001)\end{array}$ & $\begin{array}{c}0.001 \\
(0.001)\end{array}$ & $\begin{array}{c}0.005^{* *} \\
(0.001)\end{array}$ & $\begin{array}{c}0.004^{* *} \\
(0.001)\end{array}$ \\
\hline Sales growth & & $\begin{array}{c}0.033^{* *} \\
(0.001)\end{array}$ & $\begin{array}{c}0.037 * * \\
(0.001)\end{array}$ & $\begin{array}{c}0.037 * * \\
(0.001)\end{array}$ & & $\begin{array}{c}0.013^{* *} \\
(0.001)\end{array}$ & $\begin{array}{c}0.014^{* *} \\
(0.001)\end{array}$ & $\begin{array}{c}0.014^{* *} \\
(0.001)\end{array}$ \\
\hline Liquidity & & $\begin{array}{c}0.370^{* *} \\
(0.002)\end{array}$ & $\begin{array}{c}0.426^{* *} \\
(0.003)\end{array}$ & $\begin{array}{c}0.426^{* *} \\
(0.003)\end{array}$ & & $\begin{array}{c}0.133^{* *} \\
(0.001)\end{array}$ & $\begin{array}{c}0.143^{* *} \\
(0.002)\end{array}$ & $\begin{array}{c}0.141^{* *} \\
(0.002)\end{array}$ \\
\hline Leverage & & $\begin{array}{c}-0.037 * * \\
(0.001)\end{array}$ & $\begin{array}{c}-0.022 * * \\
(0.003)\end{array}$ & $\begin{array}{c}-0.021^{* *} \\
(0.003)\end{array}$ & & $\begin{array}{c}-0.061 * * \\
(0.001)\end{array}$ & $\begin{array}{c}-0.055^{* *} \\
(0.002)\end{array}$ & $\begin{array}{c}-0.055^{* *} \\
(0.002)\end{array}$ \\
\hline In(Number of Shareholders) & & $\begin{array}{c}-0.007^{* *} \\
(0.001)\end{array}$ & $\begin{array}{c}-0.009^{* *} \\
(0.002)\end{array}$ & $\begin{array}{c}-0.008^{* *} \\
(0.002)\end{array}$ & & $\begin{array}{c}-0.003 * * \\
(0.001)\end{array}$ & $\begin{array}{c}-0.004^{* *} \\
(0.002)\end{array}$ & $\begin{array}{c}-0.004 * \\
(0.002)\end{array}$ \\
\hline $\ln (\text { Sales })_{\mathrm{t}-1}$ & $\begin{array}{c}-0.004^{* *} \\
(0.001)\end{array}$ & $\begin{array}{c}0.006^{* *} \\
(0.001)\end{array}$ & $\begin{array}{c}0.003^{* *} \\
(0.001)\end{array}$ & $\begin{array}{c}0.003^{* *} \\
(0.001)\end{array}$ & $\begin{array}{c}-0.005^{* *} \\
(0.001)\end{array}$ & $\begin{array}{c}-0.003 * * \\
(0.001)\end{array}$ & $\begin{array}{c}-0.007^{* *} \\
(0.001)\end{array}$ & $\begin{array}{c}-0.007^{* * *} \\
(0.001)\end{array}$ \\
\hline Firm Age $(\times 10)$ & $\begin{array}{c}-0.018 * * \\
(0.001)\end{array}$ & $\begin{array}{c}-0.016^{* *} \\
(0.001)\end{array}$ & $\begin{array}{c}-0.033 * * \\
(0.001)\end{array}$ & $\begin{array}{c}-0.033 * * \\
(0.001)\end{array}$ & $\begin{array}{c}-0.002^{* *} \\
(0.001)\end{array}$ & $\begin{array}{c}-0.003 * * \\
(0.001)\end{array}$ & $\begin{array}{c}-0.009 * * \\
(0.001)\end{array}$ & $\begin{array}{c}-0.007 * * \\
(0.001)\end{array}$ \\
\hline
\end{tabular}

First stage (Dummmy for Married

Owners ):

Region Divorce Rate

$$
\begin{array}{cc}
-1.582 * * & -1.619^{* *} \\
(0.342) & (0.341)
\end{array}
$$

$\chi^{2}$-statistic against the null that

divorce rate is irrelevant in the first-

stage:

$29.91^{* *}$

$32.86^{* *}$

Three-digit SIC code dummies

Country dummies

Year dummies

$\begin{array}{llll}\text { Yes } & \text { Yes } & \text { Yes } & \text { Yes } \\ \text { Yes } & \text { Yes } & \text { Yes } & \text { Yes } \\ \text { Yes } & \text { Yes } & \text { Yes } & \text { Yes } \\ \text { No } & \text { No } & \text { Yes } & \text { Yes }\end{array}$

Yes Yes Yes Yes Yes

Yes Yes Yes Yes Yes

Yes Yes Yes

\section{Regional controls}

Hypotheses testing ( $p$-value $):$
(a) $=(b)$
(b) $=(\mathrm{c})$
$\mathrm{p}<0.01 \quad \mathrm{p}<0.01 \quad \mathrm{p}<0.01$
$\mathrm{p}<0.01$
$\mathrm{p}<0.01$
$\mathrm{p}<0.01$
$\mathrm{p}<0.01$
$\mathrm{p}<0.01$
$\mathrm{p}<0.01 \quad \mathrm{p}>0.10 \quad \mathrm{p}<0.01 \quad \mathrm{p}<0.01$
$\mathrm{p}<0.01$
$\mathrm{p}<0.01$
$\mathrm{p}<0.01 \quad \mathrm{p}<0.01$
(a) $=(\mathrm{c})$
$\mathrm{p}<0.01 \quad \mathrm{p}<0.01 \quad \mathrm{p}<0.01 \quad \mathrm{p}<0.01$
$\mathrm{p}<0.01$
$\mathrm{p}<0.01 \quad \mathrm{p}<0.01 \quad \mathrm{p}<0.01$

$\chi^{2}$-statistic against the null that divorce rate is irrelevant in the

\begin{tabular}{|c|c|c|c|c|c|c|c|}
\hline & & & 0.22 & & & & 0.01 \\
\hline 0.132 & 0.132 & 0.186 & 0.186 & 0.076 & 0.076 & 0.092 & 0.092 \\
\hline 0.072 & 0.514 & 0.597 & - & 0.081 & 0.272 & 0.338 & - \\
\hline $1,254,515$ & $1,071,051$ & 191,004 & 191,004 & $1,256,696$ & $1,071,051$ & 192,240 & 192,240 \\
\hline
\end{tabular}
second stage:

Observations

$\begin{array}{llllllll}1,254,515 & 1,071,051 & 191,004 & 191,004 & 1,256,696 & 1,071,051 & 192,240 & 192,240\end{array}$

Notes: This table examines the relationship between family ownership and return on assets (EBITDA over assets ) and profit margin (EBITDA over Sales ). In Columns 4 and 8, Dummy for Married Owners is instrumented by region divorce rate using a treatment effects model. Region controls include GDP, employment rate, geographical size, population size and competitiveness index. The full sample includes 272 three-digit SIC code dummies. Standard errors (in parentheses) are robust to arbitrary heteroskedasticity and allow for serial correlation through clustering by firms. * and ** indicate statistical.significance at the $5 \%$ and $1 \%$ leyel respectively.

This article is protected by copyright. All rights reserved. 
Table 5. Robustness Checks for Marriage Owner Classification and Conservatism

\begin{tabular}{|c|c|c|c|c|c|c|c|c|c|c|c|c|c|c|c|c|}
\hline & $(1)$ & $(2)$ & (3) & (4) & $(5)$ & (6) & (7) & $(8)$ & (9) & $(10)$ & (11) & $(12)$ & (13) & $(14)$ & $(15)$ & $(16)$ \\
\hline Dependent variable: & \multicolumn{4}{|c|}{ Sales growth } & \multicolumn{4}{|c|}{ Investment } & \multicolumn{4}{|c|}{ Liquidity } & \multicolumn{4}{|c|}{ Leverage } \\
\hline & \multicolumn{2}{|c|}{ "Must be married" } & \multicolumn{2}{|c|}{$\begin{array}{c}\text { "Always use husband's } \\
\text { name" }\end{array}$} & \multicolumn{2}{|c|}{ "Must be married" } & \multicolumn{2}{|c|}{$\begin{array}{c}\text { "Always use husband's } \\
\text { name" }\end{array}$} & \multicolumn{2}{|c|}{ "Must be married" } & \multicolumn{2}{|c|}{$\begin{array}{c}\text { "Always use husband's } \\
\text { name" }\end{array}$} & \multicolumn{2}{|c|}{ "Must be married" } & \multicolumn{2}{|c|}{$\begin{array}{c}\text { "Always use husband's } \\
\text { name" }\end{array}$} \\
\hline & OLS & IV & OLS & IV & OLS & IV & OLS & IV & OLS & IV & OLS & IV & OLS & IV & OLS & IV \\
\hline $\begin{array}{l}\text { Dummy for Married Family } \\
\text { wners }\end{array}$ & $\begin{array}{c}-0.037 * * \\
(0.007)\end{array}$ & $\begin{array}{l}-0.055^{* *} \\
(0.011)\end{array}$ & $\begin{array}{c}-0.025^{* *} \\
(0.002)\end{array}$ & $\begin{array}{c}-0.076^{* *} \\
(0.007)\end{array}$ & $\begin{array}{c}-0.021 * * \\
(0.005)\end{array}$ & $\begin{array}{c}-0.025^{* *} \\
(0.007)\end{array}$ & $\begin{array}{c}-0.008^{* *} \\
(0.002)\end{array}$ & $\begin{array}{c}-0.025^{* *} \\
(0.005)\end{array}$ & $\begin{array}{c}0.078^{* *} \\
(0.013)\end{array}$ & $\begin{array}{l}0.122^{* *} \\
(0.018)\end{array}$ & $\begin{array}{c}0.051^{* *} \\
(0.004)\end{array}$ & $\begin{array}{c}0.117^{* *} \\
(0.008)\end{array}$ & $\begin{array}{c}-0.059 * * \\
(0.009)\end{array}$ & $\begin{array}{c}-0.055^{* *} \\
(0.014)\end{array}$ & $\begin{array}{c}-0.018^{* *} \\
(0.003)\end{array}$ & $\begin{array}{c}-0.068^{* *} \\
(0.008)\end{array}$ \\
\hline Family Owners & $\begin{array}{c}-0.027 * * \\
(0.002)\end{array}$ & $\begin{array}{c}-0.030^{* *} \\
(0.003)\end{array}$ & $\begin{array}{c}0.002 \\
(0.002)\end{array}$ & $\begin{array}{c}-0.019^{* *} \\
(0.004)\end{array}$ & $\begin{array}{c}-0.018^{* *} \\
(0.001)\end{array}$ & $\begin{array}{c}-0.011^{* *} \\
(0.002)\end{array}$ & $\begin{array}{c}0.004 * * \\
(0.001)\end{array}$ & $\begin{array}{c}-0.006^{*} \\
(0.003)\end{array}$ & $\begin{array}{c}0.017 * * \\
(0.002)\end{array}$ & $\begin{array}{c}0.059 * * \\
(0.005)\end{array}$ & $\begin{array}{c}0.017 * * \\
(0.003)\end{array}$ & $\begin{array}{c}0.041^{* *} \\
(0.006)\end{array}$ & $\begin{array}{c}-0.034 * * \\
(0.002)\end{array}$ & $\begin{array}{c}-0.030^{* *} \\
(0.004)\end{array}$ & $\begin{array}{c}-0.013 * * \\
(0.003)\end{array}$ & $\begin{array}{c}-0.031 * * \\
(0.005)\end{array}$ \\
\hline $\begin{array}{l}\text { (c) Dummy for Unrelated } \\
\text { Qwners }\end{array}$ & $\begin{array}{c}-0.007^{* *} \\
(0.001)\end{array}$ & Base & $\begin{array}{c}0.014 * * \\
(0.002)\end{array}$ & Base & $\begin{array}{c}-0.007 * * \\
(0.001)\end{array}$ & Base & $\begin{array}{c}0.010^{* *} \\
(0.001)\end{array}$ & Base & $\begin{array}{c}-0.006^{* *} \\
(0.001)\end{array}$ & Base & $\begin{array}{c}-0.010^{* *} \\
(0.002)\end{array}$ & Base & $\begin{array}{c}-0.005^{* *} \\
(0.002)\end{array}$ & Base & $\begin{array}{c}0.011^{* *} \\
(0.002)\end{array}$ & Base \\
\hline Sales $)_{\mathrm{t}-1}$ & $\begin{array}{c}-0.103^{* *} \\
(0.001)\end{array}$ & $\begin{array}{l}-0.098^{* *} \\
(0.002)\end{array}$ & $\begin{array}{l}-0.080^{* *} \\
(0.001)\end{array}$ & $\begin{array}{c}-0.100^{* *} \\
(0.002)\end{array}$ & $\begin{array}{c}-0.046^{* *} \\
(0.001)\end{array}$ & $\begin{array}{l}-0.042^{* *} \\
(0.001)\end{array}$ & $\begin{array}{c}-0.032 * * \\
(0.001)\end{array}$ & $\begin{array}{l}-0.044^{* *} \\
(0.001)\end{array}$ & $\begin{array}{c}-0.037^{* *} \\
(0.001)\end{array}$ & $\begin{array}{c}-0.066 * * \\
(0.002)\end{array}$ & $\begin{array}{c}-0.051^{* *} \\
(0.001)\end{array}$ & $\begin{array}{c}-0.069 * * \\
(0.002)\end{array}$ & $\begin{array}{c}-0.030 * * \\
(0.001)\end{array}$ & $\begin{array}{l}-0.028^{* *} \\
(0.002)\end{array}$ & $\begin{array}{l}-0.019^{* *} \\
(0.001)\end{array}$ & $\begin{array}{c}-0.029 * * \\
(0.002)\end{array}$ \\
\hline rm Age $(\times 10)$ & $\begin{array}{c}-0.008^{* *} \\
(0.001)\end{array}$ & $\begin{array}{l}-0.120^{* *} \\
(0.002)\end{array}$ & $\begin{array}{l}-0.036^{* *} \\
(0.001)\end{array}$ & $\begin{array}{c}-0.121 * * \\
(0.002)\end{array}$ & $\begin{array}{c}-0.005 * * \\
(0.001)\end{array}$ & $\begin{array}{c}-0.065^{* *} \\
(0.001)\end{array}$ & $\begin{array}{c}-0.021 * * \\
(0.001)\end{array}$ & $\begin{array}{c}-0.064^{* *} \\
(0.002)\end{array}$ & $\begin{array}{c}-0.002 * * \\
(0.001)\end{array}$ & $\begin{array}{c}-0.047 * * \\
(0.003)\end{array}$ & $\begin{array}{c}-0.014^{* *} \\
(0.001)\end{array}$ & $\begin{array}{l}-0.055^{* *} \\
(0.003)\end{array}$ & $\begin{array}{c}-0.009 * * \\
(0.002)\end{array}$ & $\begin{array}{l}-0.078^{* *} \\
(0.003)\end{array}$ & $\begin{array}{l}-0.042^{* *} \\
(0.001)\end{array}$ & $\begin{array}{c}-0.080^{* *} \\
(0.003)\end{array}$ \\
\hline $\begin{array}{l}\text { First stage (Dummmy for } \\
\text { Married Owners): }\end{array}$ & & & & & & & & & & & & & & & & \\
\hline egion divorce rate & & $\begin{array}{c}-1.890^{* *} \\
(0.701)\end{array}$ & & $\begin{array}{c}-2.340^{* *} \\
(0.330)\end{array}$ & & $\begin{array}{c}-1.911^{* *} \\
(0.697)\end{array}$ & & $\begin{array}{l}-2.331^{* *} \\
(0.329)\end{array}$ & & $\begin{array}{c}-1.977 * * \\
(0.698)\end{array}$ & & $\begin{array}{c}-2.349 * * \\
(0.340)\end{array}$ & & $\begin{array}{c}-1.917^{* *} \\
(0.699)\end{array}$ & & $\begin{array}{c}-2.339 * * \\
(0.329)\end{array}$ \\
\hline irst-stage: & & $35.33^{* *}$ & & $52.77^{* *}$ & & $36.12^{* *}$ & & $55.04^{* *}$ & & $34.89^{* *}$ & & $53.58^{* *}$ & & $36.59^{* *}$ & & $55.66^{* *}$ \\
\hline Three-digit SIC code dummies & Yes & Yes & Yes & Yes & Yes & Yes & Yes & Yes & Yes & Yes & Yes & Yes & Yes & Yes & Yes & Yes \\
\hline Country dummies & Yes & Yes & Yes & Yes & Yes & Yes & Yes & Yes & Yes & Yes & Yes & Yes & Yes & Yes & Yes & Yes \\
\hline Year dummies & Yes & Yes & Yes & Yes & Yes & Yes & Yes & Yes & Yes & Yes & Yes & Yes & Yes & Yes & Yes & Yes \\
\hline Regional controls & No & Yes & No & Yes & No & Yes & No & Yes & No & Yes & No & Yes & No & Yes & No & Yes \\
\hline$=(b)$ & $\mathrm{p}<0.01$ & $\mathrm{p}<0.01$ & $\mathrm{p}<0.01$ & $\mathrm{p}<0.01$ & $\mathrm{p}<0.05$ & $\mathrm{p}<0.01$ & $\mathrm{p}<0.01$ & $\mathrm{p}<0.01$ & $\mathrm{p}<0.01$ & $\mathrm{p}<0.01$ & $\mathrm{p}<0.01$ & $\mathrm{p}<0.01$ & $\mathrm{p}<0.01$ & $\mathrm{p}<0.05$ & $\mathrm{p}>0.10$ & $\mathrm{p}<0.01$ \\
\hline$=(\mathrm{c})$ & $\mathrm{p}<0.01$ & $\mathrm{p}<0.01$ & $\mathrm{p}<0.01$ & $\mathrm{p}<0.01$ & $\mathrm{p}<0.01$ & $\mathrm{p}<0.01$ & $\mathrm{p}<0.05$ & $\mathrm{p}<0.05$ & $\mathrm{p}<0.01$ & $\mathrm{p}<0.01$ & $\mathrm{p}<0.05$ & $\mathrm{p}<0.01$ & $\mathrm{p}<0.01$ & $\mathrm{p}<0.01$ & $\mathrm{p}<0.01$ & $\mathrm{p}<0.01$ \\
\hline$a)=(c)$ & $\mathrm{p}<0.01$ & $\mathrm{p}<0.01$ & $\mathrm{p}<0.01$ & $\mathrm{p}<0.01$ & $\mathrm{p}<0.01$ & $\mathrm{p}<0.10$ & $\mathrm{p}<0.01$ & $\mathrm{p}<0.01$ & $\mathrm{p}<0.01$ & $\mathrm{p}<0.01$ & $\mathrm{p}<0.01$ & $\mathrm{p}<0.01$ & $\mathrm{p}<0.01$ & $\mathrm{p}<0.01$ & $\mathrm{p}<0.01$ & $\mathrm{p}<0.01$ \\
\hline nd stage: & - & 0.06 & - & 1.88 & - & 0.07 & & 0.80 & - & 0.57 & & 0.01 & & 2.08 & & 2.41 \\
\hline Sample average: & 0.200 & 0.214 & 0.188 & 0.218 & 0.137 & 0.135 & 0.120 & 0.137 & 0.286 & 0.424 & 0.361 & 0.443 & 0.749 & 0.766 & 0.747 & 0.763 \\
\hline $\mathrm{R}^{2}$ & 0.128 & - & 0.120 & - & 0.116 & - & 0.102 & - & 0.125 & - & 0.124 & - & 0.044 & - & 0.054 & - \\
\hline Observations & $1,258,172$ & 218,505 & 662,784 & 190,076 & $1,258,012$ & 221,053 & 668,789 & 192,325 & $1,078,368$ & 192,910 & 578,792 & 168,914 & $1,230,284$ & 219,782 & 665,878 & 191,116 \\
\hline
\end{tabular}


Table 6. Robustness Checks for Marriage Owner Classification and Financial Performance

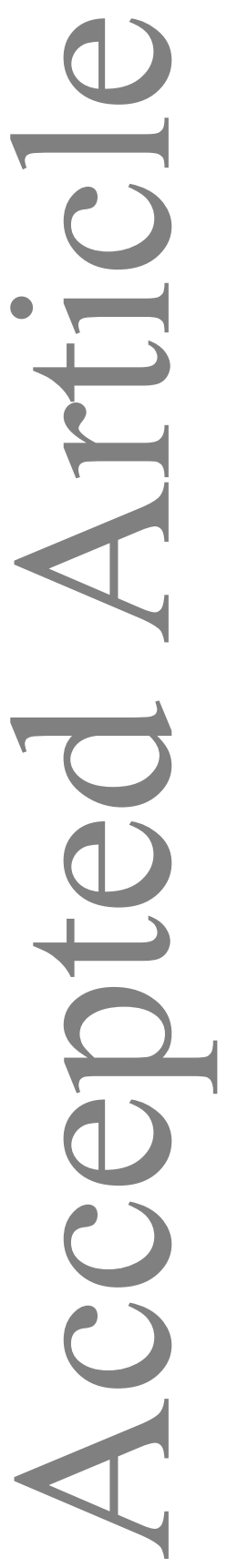

\begin{tabular}{|c|c|c|c|c|c|c|c|c|}
\hline & (1) & (2) & (3) & (4) & (5) & (6) & (7) & $(8)$ \\
\hline \multirow[t]{3}{*}{ Dependent variable: } & \multicolumn{4}{|c|}{ Return on Assets } & \multicolumn{4}{|c|}{ Profit Margin } \\
\hline & \multicolumn{2}{|c|}{ "Must be married" } & \multicolumn{2}{|c|}{$\begin{array}{c}\text { "Always use husband's } \\
\text { name" }\end{array}$} & \multicolumn{2}{|c|}{ "Must be married" } & \multicolumn{2}{|c|}{$\begin{array}{c}\text { "Always use } \\
\text { husband's name" }\end{array}$} \\
\hline & OLS & IV & OLS & IV & OLS & IV & OLS & IV \\
\hline (a) Dummy for Married Family & & & & & & & & \\
\hline $\begin{array}{l}\text { Owners } \\
\text { (b) Dummy for Non-Married Family }\end{array}$ & $\begin{array}{c}0.043^{* *} \\
(0.007)\end{array}$ & $\begin{array}{c}0.060^{* *} \\
(0.009)\end{array}$ & $\begin{array}{c}0.039^{* *} \\
(0.002)\end{array}$ & $\begin{array}{c}0.069^{* *} \\
(0.004)\end{array}$ & $\begin{array}{l}0.024 * * \\
(0.004)\end{array}$ & $\begin{array}{c}0.033^{* *} \\
(0.005)\end{array}$ & $\begin{array}{c}0.017^{* *} \\
(0.001)\end{array}$ & $\begin{array}{c}0.041^{* *} \\
(0.003)\end{array}$ \\
\hline Owners & $\begin{array}{c}0.009 * * \\
(0.001)\end{array}$ & $\begin{array}{c}0.034 * * \\
(0.002)\end{array}$ & $\begin{array}{c}0.012^{* *} \\
(0.002)\end{array}$ & $\begin{array}{c}0.021^{* *} \\
(0.003)\end{array}$ & $\begin{array}{l}0.008^{* *} \\
(0.001)\end{array}$ & $\begin{array}{c}0.020^{* *} \\
(0.001)\end{array}$ & $\begin{array}{c}0.007 * * \\
(0.001)\end{array}$ & $\begin{array}{c}0.016^{* *} \\
(0.002)\end{array}$ \\
\hline (c) Dummy for Unrelated Owners & $\begin{array}{l}-0.000 \\
(0.001)\end{array}$ & Base & $\begin{array}{l}-0.001 \\
(0.001)\end{array}$ & Base & $\begin{array}{l}-0.001^{*} \\
(0.002)\end{array}$ & Base & $\begin{array}{c}-0.004^{* *} \\
(0.001)\end{array}$ & Base \\
\hline $\ln (\text { Sales })_{\mathrm{t}-1}$ & $\begin{array}{c}-0.008^{* *} \\
(0.001)\end{array}$ & $\begin{array}{c}-0.020^{* *} \\
(0.001)\end{array}$ & $\begin{array}{c}-0.010^{* *} \\
(0.001)\end{array}$ & $\begin{array}{c}-0.023 * * \\
(0.001)\end{array}$ & $\begin{array}{c}-0.006 * * \\
(0.0002)\end{array}$ & $\begin{array}{c}-0.012^{* *} \\
(0.001)\end{array}$ & $\begin{array}{c}-0.009 * * \\
(0.0003)\end{array}$ & $\begin{array}{c}-0.014^{* *} \\
(0.001)\end{array}$ \\
\hline Firm Age $(\times 10)$ & $\begin{array}{c}-0.003 * * \\
(0.001)\end{array}$ & $\begin{array}{c}-0.051^{* *} \\
(0.002)\end{array}$ & $\begin{array}{c}0.034^{* *} \\
(0.001)\end{array}$ & $\begin{array}{c}-0.055^{* * *} \\
(0.002)\end{array}$ & $\begin{array}{l}0.001^{* *} \\
(0.0003)\end{array}$ & $\begin{array}{c}-0.010^{* *} \\
(0.001)\end{array}$ & $\begin{array}{c}0.005^{* *} \\
(0.001)\end{array}$ & $\begin{array}{c}-0.009^{* *} \\
(0.001)\end{array}$ \\
\hline
\end{tabular}

First stage (Dummmy for Married

Owners ):

Region Divorce Rate

$(0.704)$

$-2.303 * *$

$-1.919^{* *}$

$-2.343^{* *}$

$\chi^{2}$-statistic against the null that

divorce rate is irrelevant in the first-

stage:

$34.59^{* *}$

$36.77^{* *}$

$55.58^{* *}$

Three-digit SIC code dummies

Country dummies

Year dummies

Regional controls

Hypotheses testing (p-value ):

(a) $=$ (b)

$(\mathrm{b})=(\mathrm{c})$

Yes Yes

Yes $\quad$ Yes

Yes Yes

No Yes

Yes

$\chi^{2}$-statistic against the null that

divorce rate is irrelevant in the second

stage:

0.65

Sample average: 
Table 7. Effects of Ownership Changes on Sales Growth, Investment, and ROA

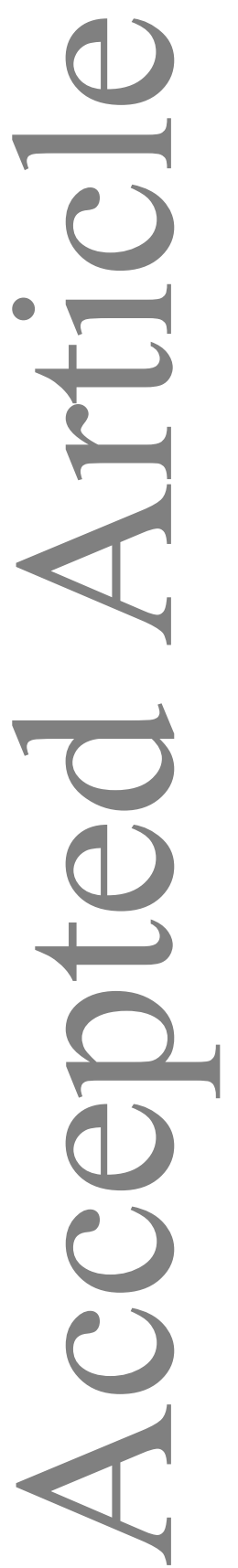

\begin{tabular}{|c|c|c|c|c|c|c|c|c|c|}
\hline & (1) & $(2)$ & (3) & (4) & $(5)$ & $(6)$ & (7) & $(8)$ & (9) \\
\hline Ownership change: & \multicolumn{3}{|c|}{ Married Family to Unrelated } & \multicolumn{3}{|c|}{ Non-Married Family to Unrelated } & \multicolumn{3}{|c|}{ Unrelated to Unrelated } \\
\hline Dependent variable: & $\begin{array}{c}\Delta \text { Sales } \\
\text { Growth, } \\
2007-2011\end{array}$ & $\begin{array}{c}\Delta \text { Invest- } \\
\text { ment } \\
2007-2011\end{array}$ & $\begin{array}{c}\Delta \mathrm{ROA}, \\
2007-2011\end{array}$ & $\begin{array}{c}\Delta \text { Sales } \\
\text { Growth, } \\
2007-2011\end{array}$ & $\begin{array}{c}\Delta \text { Invest- } \\
\text { ment } \\
2007-2011\end{array}$ & $\begin{array}{c}\Delta \mathrm{ROA}, \\
2007-2011\end{array}$ & $\begin{array}{c}\Delta \text { Sales } \\
\text { Growth, } \\
2007-2011\end{array}$ & $\begin{array}{c}\Delta \text { Invest- } \\
\text { ment, } \\
2007-2011\end{array}$ & $\begin{array}{c}\Delta \mathrm{ROA}, \\
2007-2011\end{array}$ \\
\hline Dummy for Ownership Change & $\begin{array}{c}0.051 * * \\
(0.018)\end{array}$ & $\begin{array}{c}0.059 * * \\
(0.014)\end{array}$ & $\begin{array}{c}-0.029 * * \\
(0.010)\end{array}$ & $\begin{array}{l}0.013 \\
(0.022)\end{array}$ & $\begin{array}{l}0.019 \\
(0.012)\end{array}$ & $\begin{array}{c}0.032 * * \\
(0.010)\end{array}$ & $\begin{array}{l}-0.003 \\
(0.006)\end{array}$ & $\begin{array}{l}0.021 \\
(0.012)\end{array}$ & $\begin{array}{c}0.034 * * \\
(0.003)\end{array}$ \\
\hline $\ln ($ Sales $)$ & $\begin{array}{c}0.067 * * \\
(0.004)\end{array}$ & $\begin{array}{c}0.017 * * \\
(0.003)\end{array}$ & $\begin{array}{c}0.021 * * \\
(0.001)\end{array}$ & $\begin{array}{c}0.048 * * \\
(0.002)\end{array}$ & $\begin{array}{l}0.002 \\
(0.003)\end{array}$ & $\begin{array}{c}0.017 * * \\
(0.001)\end{array}$ & $\begin{array}{c}0.074 * * \\
(0.001)\end{array}$ & $\begin{array}{c}0.049 * * \\
(0.002)\end{array}$ & $\begin{array}{c}0.015 * * \\
(0.001)\end{array}$ \\
\hline Firm Age $(\times 10)$ & $\begin{array}{l}0.002 \\
(0.002)\end{array}$ & $\begin{array}{l}0.001 \\
(0.001)\end{array}$ & $\begin{array}{l}0.001 \\
(0.001)\end{array}$ & $\begin{array}{c}0.002 * \\
(0.001)\end{array}$ & $\begin{array}{l}-0.001 \\
(0.001))\end{array}$ & $\begin{array}{c}0.002 * \\
(0.001)\end{array}$ & $\begin{array}{c}0.001 * * \\
(0.0001)\end{array}$ & $\begin{array}{l}0.002 \\
(0.002)\end{array}$ & $\begin{array}{c}0.001 * * \\
(0.0001)\end{array}$ \\
\hline Observations & 80,369 & 94,474 & 82,707 & 80,369 & 94,474 & 82,707 & 80,369 & 94,474 & 82,707 \\
\hline $\mathrm{R}^{2}$ & 0.072 & 0.033 & 0.017 & 0.073 & 0.034 & 0.019 & 0.073 & 0.034 & 0.019 \\
\hline$\Delta$ Sample Average & -0.285 & -0.181 & -0.121 & -0.285 & -0.181 & -0.121 & -0.285 & -0.181 & -0.121 \\
\hline
\end{tabular}

This article is protected by copyright. All rights reserved. 
Table 8. Ownership Concentration in Family Firms

\begin{tabular}{|c|c|c|c|c|c|c|c|c|c|c|c|c|}
\hline & (1) & (2) & (3) & (4) & $(5)$ & (6) & (7) & $(8)$ & (9) & $(10)$ & (11) & $(12)$ \\
\hline Dependent variable: & \multicolumn{4}{|c|}{ Sales growth } & \multicolumn{4}{|c|}{ vestment } & \multicolumn{4}{|c|}{ n on Assets } \\
\hline
\end{tabular}

Firm sample:

(a) Dummy for Married Family

Owners

(b) Dummy for Non-Married

Family Owners

(c) Dummy for Unrelated

Owners

Multi-owner

Family

Multi-owner Family

Multi-owner

Family

\begin{tabular}{|c|c|c|c|c|c|c|c|c|c|c|c|}
\hline $\begin{array}{c}-0.014 * * \\
(0.002)\end{array}$ & $\begin{array}{c}-0.011 * * \\
(0.002)\end{array}$ & $\begin{array}{c}-0.012 * * \\
(0.002)\end{array}$ & $\begin{array}{c}-0.011 * * \\
(0.002)\end{array}$ & $\begin{array}{c}-0.011 * * \\
(0.001)\end{array}$ & $\begin{array}{c}-0.013 * * \\
(0.001)\end{array}$ & $\begin{array}{c}-0.005^{* *} \\
(0.001)\end{array}$ & $\begin{array}{c}-0.005^{* *} \\
(0.001)\end{array}$ & $\begin{array}{c}0.048 * * \\
(0.001)\end{array}$ & $\begin{array}{c}0.033 * * \\
(0.002)\end{array}$ & $\begin{array}{c}0.014 * * \\
(0.001)\end{array}$ & $\begin{array}{c}0.012 * * \\
(0.002)\end{array}$ \\
\hline $\begin{array}{l}-0.002 \\
(0.002)\end{array}$ & $\begin{array}{c}0.001 \\
(0.002)\end{array}$ & Base & Base & $\begin{array}{l}-0.001 \\
(0.001)\end{array}$ & $\begin{array}{l}-0.001 \\
(0.001)\end{array}$ & Base & Base & $\begin{array}{c}0.014^{* *} \\
(0.001)\end{array}$ & $\begin{array}{c}0.004^{* *} \\
(0.001)\end{array}$ & Base & Base \\
\hline Base & Base & & & Base & Base & & & Base & Base & & \\
\hline
\end{tabular}

Share equity by dominant family

shareholders

\begin{tabular}{|c|c|c|c|c|c|c|c|c|c|c|}
\hline $008^{* *}$ & & $\begin{array}{c}-0.009 * * \\
(0.003)\end{array}$ & & $\begin{array}{c}0.005^{* *} \\
(0.001)\end{array}$ & & $\begin{array}{l}0.004 * \\
(0.002)\end{array}$ & & $\begin{array}{c}0.037 * * \\
(0.002)\end{array}$ & & $\begin{array}{c}0.013 * * \\
(0.002)\end{array}$ \\
\hline $\begin{array}{l}065^{* *} \\
.001)\end{array}$ & $\begin{array}{c}-0.068 * * \\
(0.001)\end{array}$ & $\begin{array}{c}-0.068 * * \\
(0.001)\end{array}$ & $\begin{array}{c}-0.024 * * \\
(0.001)\end{array}$ & $\begin{array}{c}-0.024 * * \\
(0.001)\end{array}$ & $\begin{array}{c}-0.031 * * \\
(0.001)\end{array}$ & $\begin{array}{c}-0.031 * * \\
(0.001)\end{array}$ & $\begin{array}{c}-0.002 * * \\
(0.0003)\end{array}$ & $\begin{array}{c}-0.001 * * \\
(0.0003)\end{array}$ & $\begin{array}{c}-0.009 * * \\
(0.001)\end{array}$ & $\begin{array}{c}-0.009 * * \\
(0.001)\end{array}$ \\
\hline & $\begin{array}{c}-0.029 * * \\
(0.001)\end{array}$ & $\begin{array}{c}-0.029 * * \\
(0.001)\end{array}$ & $\begin{array}{c}-0.029 * * \\
(0.001)\end{array}$ & $\begin{array}{c}-0.029 * * \\
(0.001)\end{array}$ & $\begin{array}{c}-0.004 * * \\
(0.001)\end{array}$ & $\begin{array}{c}-0.004 * * \\
(0.001)\end{array}$ & $\begin{array}{c}-0.018^{* *} \\
(0.001)\end{array}$ & $\begin{array}{c}-0.017 * * \\
(0.001)\end{array}$ & $\begin{array}{c}-0.021 * * \\
(0.001)\end{array}$ & $\begin{array}{c}-0.021 * * \\
(0.001)\end{array}$ \\
\hline
\end{tabular}

Firm Age $(\times 10)$

Three-digit SIC code dummies

Country dummies

Year dummies

Hypotheses testing ( $p$-value ):
(a) $=(\mathrm{b})$
(b) $=(\mathrm{c})$
(a) $=(\mathrm{c})$

$\begin{array}{cccc}\mathrm{p}<0.01 & \mathrm{p}<0.01 & \mathrm{p}<0.01 & \mathrm{p}<0.01 \\ \mathrm{p}>0.10 & \mathrm{p}>0.10 & - & - \\ \mathrm{p}<0.01 & \mathrm{p}<0.01 & - & -\end{array}$

$\begin{array}{cccc}\text { Yes } & \text { Yes } & \text { Yes } & \text { Yes } \\ \text { Yes } & \text { Yes } & \text { Yes } & \text { Yes } \\ \text { Yes } & \text { Yes } & \text { Yes } & \text { Yes }\end{array}$

$\begin{array}{cccc}\text { Yes } & \text { Yes } & \text { Yes } & \text { Yes } \\ \text { Yes } & \text { Yes } & \text { Yes } & \text { Yes } \\ \text { Yes } & \text { Yes } & \text { Yes } & \text { Yes }\end{array}$

Sample average:

$\begin{array}{llll}0.200 & 0.200 & 0.161 & 0.161\end{array}$

$\mathrm{p}<0.01 \quad \mathrm{p}<0.01 \quad \mathrm{p}<0.01 \quad \mathrm{p}<0.01$

$\mathrm{p}<0.01 \quad \mathrm{p}<0.01 \quad \mathrm{p}<0.01 \quad \mathrm{p}<0.01$

$\mathrm{p}>0.10 \quad \mathrm{p}>0.10$

$\mathrm{p}<0.01 \quad \mathrm{p}<0.0$

$\mathrm{p}<0.01 \quad \mathrm{p}<0.01$

$\mathrm{p}<0.01 \quad \mathrm{p}<0.0$

$\mathrm{R}^{2}$

$\begin{array}{llll}0.119 & 0.119 & 0.125 & 0.125\end{array}$

0.129

0.129

0.116

0.116

0.132

0.132

0.146

0.146

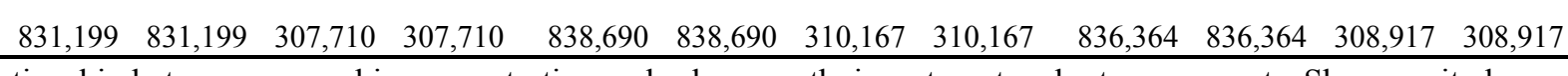

Observations

Notes: This table examines the relationship between ownership concentration and sales growth, investment and return on assets. Share equity by dominant family shareholders is the share of equity at the surname level (the sum of equity held by shareholders that have the same surname). Standard errors (in parentheses) are robust to arbitrary heteroskedasticity and allow for serial correlation through clustering by firms. * and ** indicate statistical significance at the $5 \%$ and $1 \%$ level, respectively.

This article is protected by copyright. All rights reserved. 
Table 9. Wages

\begin{tabular}{|c|c|c|c|c|c|c|}
\hline \multicolumn{7}{|c|}{ Dependent variable: $\ln ($ Wage per employee $)$} \\
\hline & $(1)$ & $(2)$ & (3) & $(4)$ & $(5)$ & $(6)$ \\
\hline Estimation: & OLS & OLS & OLS & IV & IV & IV \\
\hline Sample & All & All & All & All & $\begin{array}{c}\text { Firm } \\
\text { Age }>1^{\text {st }} \\
\text { quartile }\end{array}$ & $\begin{array}{c}\text { No. } \\
\text { employees } \\
>1^{\text {st }} \\
\text { quartile } \\
\end{array}$ \\
\hline $\begin{array}{l}\text { Dummy for Family Owners } \\
\text { (a) Dummy for Married Family }\end{array}$ & $\begin{array}{c}-0.041 * * \\
(0.003)\end{array}$ & & & & & \\
\hline Owners & & $\begin{array}{c}-0.040 * * \\
(0.004)\end{array}$ & $\begin{array}{c}-0.042 * * \\
(0.005)\end{array}$ & $\begin{array}{c}-0.161 * * \\
(0.031)\end{array}$ & $\begin{array}{c}0.142 * * \\
(0.039)\end{array}$ & $\begin{array}{c}-0.107 * * \\
(0.026)\end{array}$ \\
\hline $\begin{array}{l}\text { (b) Dummy for Non-Married } \\
\text { Family Owners }\end{array}$ & & $\begin{array}{l}-0.042 * * \\
(0.003)\end{array}$ & $\begin{array}{c}-0.044 * * \\
(0.004)\end{array}$ & $\begin{array}{c}-0.061 * * \\
(0.010)\end{array}$ & $\begin{array}{c}-0.057 * * \\
(0.012)\end{array}$ & $\begin{array}{c}-0.059 * * \\
(0.011)\end{array}$ \\
\hline (c) Dummy for Unrelated Owners & $\begin{array}{c}-0.006^{* *} \\
(0.002)\end{array}$ & $\begin{array}{c}-0.006^{*} \\
(0.002)\end{array}$ & $\begin{array}{c}-0.008 * * \\
(0.003)\end{array}$ & Base & Base & Base \\
\hline Dummy for Female Owner & & & $\begin{array}{l}0.003 \\
(0.003)\end{array}$ & & & \\
\hline $\ln (\text { Sales })_{\mathrm{t}-1}$ & $\begin{array}{c}0.114^{* *} \\
(0.001)\end{array}$ & $\begin{array}{c}0.114 * * \\
(0.001)\end{array}$ & $\begin{array}{c}0.115^{* *} \\
(0.001)\end{array}$ & $\begin{array}{c}0.187 * * \\
(0.004)\end{array}$ & $\begin{array}{c}0.176^{* *} \\
(0.004)\end{array}$ & $\begin{array}{l}0.184 * * \\
(0.004)\end{array}$ \\
\hline Firm Age $(\times 10)$ & $\begin{array}{c}0.012 * * \\
(0.001)\end{array}$ & $\begin{array}{c}0.012 * * \\
(0.001)\end{array}$ & $\begin{array}{c}0.012 * * \\
(0.001)\end{array}$ & $\begin{array}{c}0.021 * * \\
(0.006)\end{array}$ & $\begin{array}{c}0.016^{* *} \\
(0.008)\end{array}$ & $\begin{array}{c}0.030^{* *} \\
(0.006)\end{array}$ \\
\hline \multicolumn{7}{|l|}{$\begin{array}{l}\text { First stage (Dummmy for Married } \\
\text { Owners ): }\end{array}$} \\
\hline Region Divorce Rate & & & & $\begin{array}{c}-1.624 * * \\
(0.560)\end{array}$ & $\begin{array}{c}-1.854 * * \\
(0.670)\end{array}$ & $\begin{array}{c}-1.935^{* *} \\
(0.691)\end{array}$ \\
\hline $\begin{array}{l}\chi^{2} \text {-statistic against the null that } \\
\text { divorce rate is irrelevant in the first- } \\
\text { stage: }\end{array}$ & & & & $30.68 * *$ & $15.51 * *$ & $17.01 * *$ \\
\hline $\begin{array}{l}\text { Three-digit SIC code dummies } \\
\text { Country dummies } \\
\text { Year dummies } \\
\text { Region controls }\end{array}$ & $\begin{array}{l}\text { Yes } \\
\text { Yes } \\
\text { Yes } \\
\text { No }\end{array}$ & $\begin{array}{l}\text { Yes } \\
\text { Yes } \\
\text { Yes } \\
\text { No }\end{array}$ & $\begin{array}{l}\text { Yes } \\
\text { Yes } \\
\text { Yes } \\
\text { No }\end{array}$ & $\begin{array}{l}\text { Yes } \\
\text { Yes } \\
\text { Yes } \\
\text { Yes }\end{array}$ & $\begin{array}{l}\text { Yes } \\
\text { Yes } \\
\text { Yes } \\
\text { Yes }\end{array}$ & $\begin{array}{l}\text { Yes } \\
\text { Yes } \\
\text { Yes } \\
\text { Yes }\end{array}$ \\
\hline \multicolumn{7}{|l|}{ Hypotheses testing (p-value $)$ : } \\
\hline$(a)=(b)$ & - & $\mathrm{p}>0.10$ & $\mathrm{p}>0.10$ & $\mathrm{p}<0.01$ & $\mathrm{p}<0.01$ & $\mathrm{p}<0.05$ \\
\hline$(b)=(c)$ & - & $\mathrm{p}<0.01$ & $\mathrm{p}<0.01$ & $\mathrm{p}<0.01$ & $\mathrm{p}<0.01$ & $\mathrm{p}<0.01$ \\
\hline$(a)=(b)=(c)$ & - & $\mathrm{p}<0.01$ & $\mathrm{p}<0.01$ & $\mathrm{p}<0.01$ & $\mathrm{p}<0.01$ & $\mathrm{p}<0.01$ \\
\hline $\begin{array}{l}\chi^{2} \text {-statistic against the null that } \\
\text { divorce rate is irrelevant in the } \\
\text { second stage: }\end{array}$ & & & & 2.28 & 2.33 & 0.36 \\
\hline Sample average: & 3.61 & 3.61 & 3.61 & 3.70 & 3.70 & 3.70 \\
\hline $\mathrm{R}^{2}$ & 0.302 & 0.302 & 0.296 & - & - & - \\
\hline Observations & 748,159 & 748,159 & 748,159 & 86,616 & 66,231 & 53,728 \\
\hline
\end{tabular}

Notes: This table examines the relationship between family ownership and average employee wage. In Columns 4-6, Dummy for Married Family Owners is instrumented by region divorce rate using a treatment effects model. Region controls include GDP, employment rate, geographical size, population size and competitiveness index. Standard errors (in parentheses) are robust to arbitrary heteroskedasticity and allow for serial correlation through clustering by firms. $*$ and $* *$ indicate statistical significance at the $5 \%$ and $1 \%$ level, respectively.

This article is protected by copyright. All rights reserved. 
Table 10. Firm Survival: Cox Hazard Models

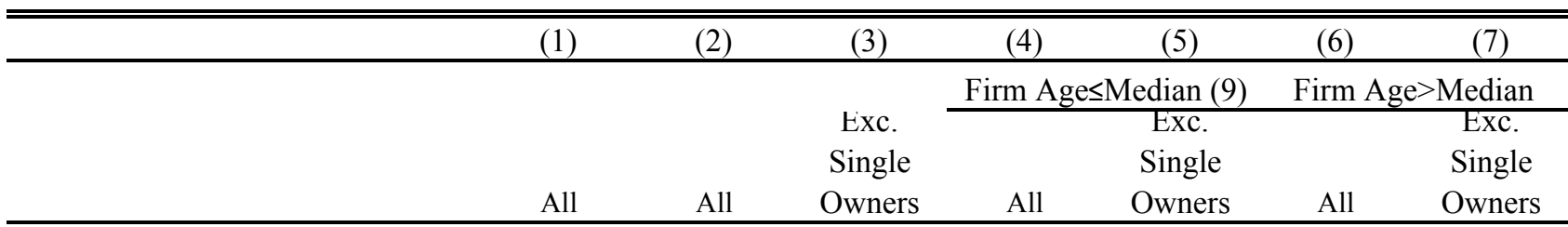

(a) Dummy for Married Family

Owners

(b) Dummy for Non-Married

Family Owners

(c) Dummy for Unrelated

Owners

Dummy for Female Owner

Firm Age

$\ln$ (Sales)

ROA

Liquidity

Leverage

Hypotheses testing ( $p$-value ):

(a) $=$ (b)

(b) $=(\mathrm{c})$

(a) $=(\mathrm{c})$

Observations

$\mathrm{Chi}^{2}$

$\%$ exit

$\mathrm{p}<0.05$

$\mathrm{p}<0.01$

$\mathrm{p}=0.09$

$\mathrm{p}>0.10$

$\mathrm{p}<0.0$

$\mathrm{p}<0.01$

$\mathrm{p}<0.01$

$\mathrm{p}<0.01$

228,230

188,209

122,945

136,875

85,040

51,334

37,905

29,359

$23,170.6$

$15,084.0$

$15,515.1$

$9,759.3$

$4,759.1$

$3,372.0$

14.5

13.8

13.4

14.4

14.2

12.0

11.5 ownership on firm exit. The time variable in the hazard models is time to exit, which is a censored variable. A firm is labeled as having exited if it submits its most recent report before 2005. All models include year, industry and country dummies. Hazard ratios are reported. Standard errors (in brackets) are robust to arbitrary heteroskedasticity. * and ** indicate statistical significance at the $5 \%$ and $1 \%$ level, respectively.

This article is protected by copyright. All rights reserved. 